\title{
44. LATE PLIOCENE TO HOLOCENE PLANKTONIC FORAMINIFERS OF THE GUAYMAS BASIN, GULF OF CALIFORNIA, SITES 477 THROUGH $481^{1}$
}

\author{
Y. Matoba, Institute of Mining Geology, Mining College, Akita University, Akita, Japan \\ and \\ M. Oda, Institute of Geology and Paleontology, Tohoku University, Sendai, Japan
}

\begin{abstract}
Eight holes were drilled at five sites in the Guaymas Basin in the central part of the Gulf of California during Deep Sea Drilling Project (DSDP) Leg 64. Holes 477, 477A, 477B, 481, and 481A were drilled in the two spreading rifts in the central part of the basin, and Hole 478 was drilled in the flat basin floor. The sediment dates from the Pleistocene to Holocene epoch. Sites 479 and 481 are on the continental slope within the depths of the present oxygen-minimum zone. The six basal cores from Hole 479 are from the late Pliocene epoch, and an unconformity seems to occur between the upper Pliocene and the overlying Pleistocene sequence. Hole 480 was drilled with a hydraulic piston corer and contains an upper Pleistocene to Holocene sequence of well-laminated diatomaceous mud.

Almost all specimens of Neogloboquadrina pachyderma are dextrally coiled in the upper Pliocene to Holocene sequence. Tropical and subtropical species occur in many samples but are not abundant. Such temperate forms as Globigerina bulloides bulloides, G. bulloides quadrilatera, G. bulloides umbilicata, Globigerinita glutinata, Neogloboquadrina dutertrei forma $\mathrm{A}$, and $N$. pachyderma forma $\mathrm{A}$ and forma $\mathrm{B}$ are predominant in the Pleistocene to Holocene sequence. The late Pliocene fauna from the basal part of the Hole 479 is abundant in Globigerinoides and includes Globigerinoides bollii, G. obliquus, and sinistrally coiled Pulleniatina obliquiloculata. The upper Pleistocene to Holocene sequence is characterized by the abundant and continuous occurrence of Globigerina bulloides quadrilatera and $G$. bulloides umbilicata. Evidence for three cooler intervals occurring in the middle to late Pleistocene epoch is apparent, but the climatic fluctuation indicated by planktonic foraminifers differs from that of the northeast Pacific Ocean, probably because of the geography, geomorphology, and the special paleoceanographic conditions of the Gulf. The proto-Gulf sequence defined on the reflection profiles includes the uppermost Pliocene. The angular unconformity between the proto-Gulf sequence and the younger sediment was formed in the early Pleistocene epoch, during the opening of the Gulf, rather than at the beginning of the present spreading phase. Many of the planktonic foraminiferal species and morphotypes are illustrated in the plates. One species, Turborotalita guaymasensis n. sp., is new.
\end{abstract}

\section{INTRODUCTION ${ }^{2}$}

Leg 64 included two distinct drilling areas: off the tip of Baja California and the Guaymas Basin in the central part of the Gulf of California. We studied planktonic foraminifers from the upper Pliocene to Holocene sections in the Guaymas Basin (Fig. 1).

The primary purposes of drilling were to investigate the nature of the ocean crust currently generated in the Gulf, where sedimentation rates are very high (Moore, 1973), and to study the paleoceanography and biostratigraphy of the laminated diatomaceous sediment on the continental slope in the central Gulf. The Guaymas Basin includes two spreading rifts separated by a $20-\mathrm{km}$ transform fault. Sites 477 and 481 are in the south and north rifts, respectively. The sediment includes Quaternary diatom ooze and turbidites intruded by basalt, dolerite, and gabbro sills. Site 478 is on the basin floor -northwest of the south rift-over postulated young crust. Its sequence is similar to that of Sites 477 and 481 . Sites 479 and 480 are on the northern continental slope of the Guaymas Basin within the present oxygen-minimum layer and over the presumed proto-Gulf sediment and crust (Moore, 1973). Hole 479 penetrated 444 meters of diatomaceous ooze to laminated mudstone. Sedi-

\footnotetext{
${ }^{1}$ Curray, J., Moore, D. G., et al., Init. Repts. DSDP, 64: Washington (U.S. Govt. Printing Office).

${ }^{2}$ For the geographic and hydrographic setting, see Matoba and Yamaguchi (this volume).
}

ment from the lowest part of the hole contains a late Pliocene planktonic foraminiferal fauna. Hole $480 \mathrm{du}-$ plicated the upper 152 meters of Hole 479 and was drilled with the newly developed hydraulic piston corer.

Bradshaw (1959), Bandy (1961), and Parker (1973) reported on the Recent distribution of planktonic foraminifers in the Gulf. Miocene to Pleistocene foraminifers from deposits exposed on islands and on the continental slope in the Gulf are included in the papers of Natland (1950) and Moore (1973), respectively. Smith (1970) and Ingle (1973c, 1974) studied planktonic and benthic foraminifers of upper Miocene to Pliocene land sections and wells in the northern extensions of the Gulf.

\section{METHODS}

We examined 258 sediment samples from Holes 477 to $481 \mathrm{~A}$ in the Guaymas Basin; planktonic foraminifers occur in 129 samples. Each sample contained about $10 \mathrm{~cm}^{3}$ of sediment. We disaggregated the samples by soaking them in warm water and by adding varying amounts of hydrogen peroxide, depending on the consolidation of the sediment.

We washed the disaggregated samples through a 250 -mesh $(0.063$ $\mathrm{mm}$ ) screen and allowed them to dry. Diatomaceous sediment samples, especially those from a few top cores of each hole, contained abundant diatom remains, which flocculated as they dried. We boiled these samples in a concentrated solution of sodium hydroxide to dissolve diatom silica. Before extracting the foraminifers, each sample was dry sieved through a 115 -mesh $(0.125$ - $\mathrm{mm})$ screen, and the coarser fraction was analyzed for foraminifers. Where planktonic foraminifers were abundant, the samples were split into a workable size and 200 to 300 


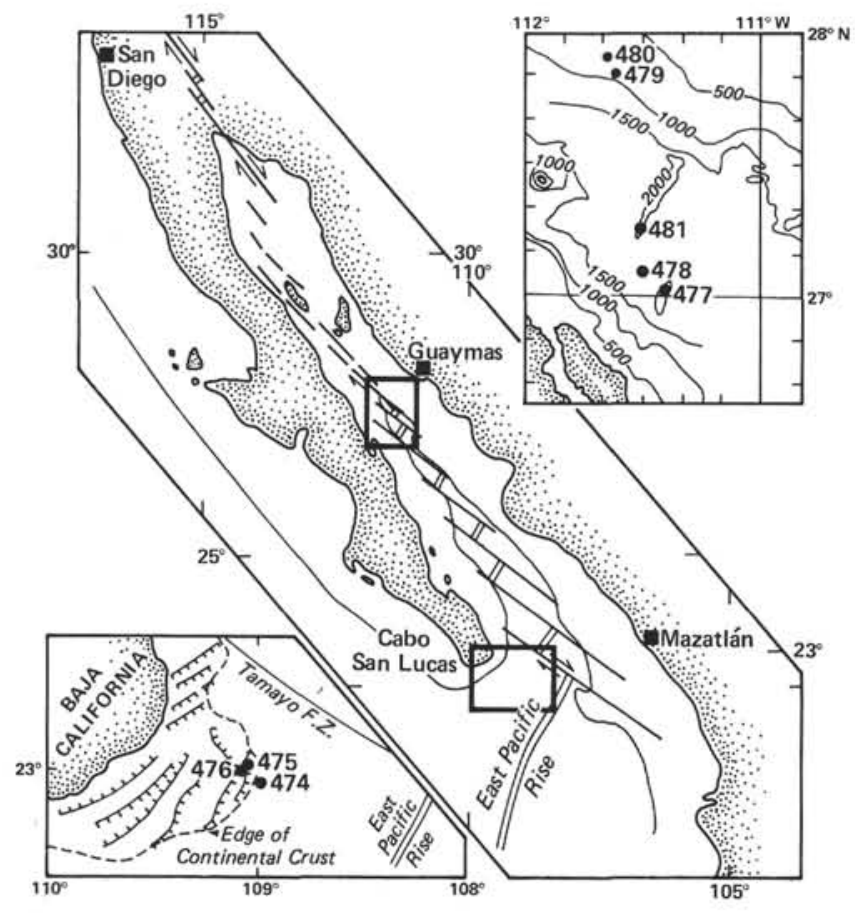

Figure 1. Guaymas Basin sites, Leg 64 (from Curray et al., 1979).

specimens were extracted. We extracted the benthic foraminifers from the same split.

We conducted quantitative analyses of planktonic foraminifers, and the results are given on Tables 1 through 5 (occurrence in percentages). Percentages were not calculated for samples containing fewer than 30 specimens. The stratigraphic occurrences of some selected species are shown in Figures 3 through 7. Most species and morphotypes are illustrated in SEM photographs on Plates 1 through 5.

\section{PRESERVATION AND ABUNDANCE}

Preservation, abundance of benthic and planktonic foraminifers, and the ratio of planktonic foraminifers to total foraminifers are shown in Figure 2. Preservation of foraminiferal tests is poor in many samplesand for two reasons: simple dissolution and thermal alteration.

The deeper sites (Sites 477, 478, and 481), are intruded by basaltic sills. Near the sills, there is a change in the foraminiferal tests: The test walls are brown or recrystallized. In samples from the upper part of each hole (above the sills), however, preservation is moderately good, except where strong dissolution has occurred; preservation is better than in the shallower sites (Sites 479 and 480 ). At Sites 479 and 480 , which are within the present oxygen-minimum zone, preservation is generally poor throughout because of strong dissolution.

We calculated the abundance of benthic and planktonic foraminifers as the number of specimens in $10 \mathrm{ml}$ of sediment. This abundance seems to be related to preservation; planktonic and benthic foraminifers are more abundant in the deeper holes. In these deeper holes, planktonic foraminifers are more abundant than benthic foraminifers. Nonetheless, in many samples from shallower holes, there are fewer planktonic than benthic foraminifers and in some samples, planktonic foraminifers are absent entirely. This may be the result of selec- tive dissolution between benthic and planktonic foraminifers. Parker and Berger (1971), in their study of deep-sea sediment, noted that the ratio of planktonic to benthic foraminifers is a function of preservation. This ratio may also hold for continental slope and basin sediment in environments of strong dissolution, such as the bottom of the present oxygen-minimum zone in the Guaymas Basin.

\section{GEOGRAPHICAL DISTRIBUTION}

Planktonic foraminiferal species have different geographic distributions in the oceans, and this distribution generally accords with major hydrographic regions. Although the distribution is controlled physically, chemically, and biologically, temperature is probably the most important variable for most species. There are five major faunal provinces: the arctic and antarctic, subarctic and subantarctic, subtropical, tropical provinces, and the transition zones between subpolar and subtropical provinces (Bé and Tolderlund, 1971; Bé, 1977). To distinguish the paleoceanographic variations in the Gulf of California, we examined the occurrence of warmand cold-water species in the fauna of the Guaymas Basin. Warm-water species (according to Bradshaw, 1959; Parker and Berger, 1971; Bé and Tolderlund, 1971; Bé, 1977 ) in the Basin fauna are as follows: Globigerinella aequilateralis, Globigerinoides conglobatus, G. quadrilobatus (s.1.), G. ruber (s.1.), Globorotalia cultrata, G. fimbriata, G. hirsuta, G. tumida, Pulleniatina obliquiloculata, and the fossil species of Globigerinoides bollii and $G$. obliquus. The characteristic arctic species, the left-coiling form of Neogloboquadrina pachyderma, is nearly absent in the Basin fauna. Therefore, the rightcoiling form of $N$. pachyderma, which is distributed in the subarctic-to-transition area, is the relatively colderwater species in the Guaymas Basin samples.

\section{SITE 477}

The stratigraphic section at Site 477 consists of Holes 477 and $477 \mathrm{~A}$. The occurrence of planktonic foraminifers at Site 477 is shown in Table 1 and Figure 3. Statistically reliable occurrences of planktonic foraminifers were found only in the upper part of Sample 477-7-2, $17-19 \mathrm{~cm}$, above the dolerite sill. Globigerina bulloides bulloides, $G$. bulloides quadrilatera, $G$. bulloides umbilicata, Globigerinita glutinata, Neogloboquadrina dutertrei forma A, and N. pachyderma forma B are common throughout most of this interval. Neogloboquadrina pachyderma (s.s.) and $N$. dutertrei blowi occur only in Sections 477-7-1 and 477-7-2. Warm-water species occur in Sections 477-5-1, 477-7-1, and 477-7-2 with frequencies of 6 to $17 \%$.

\section{SITE 478}

In Hole 478, foraminifers are absent in two intervals between Cores 478-23 and 478-27 and below Core 47840 , where basalt and dolerite sills have intruded (Table 2; Fig. 4).

Globigerina bulloides bulloides, Neogloboquadrina dutertrei forma $\mathrm{A}$, and $N$. pachyderma forma B are the most abundant nearly throughout the hole. Globigerina 
bulloides quadrilatera and $G$. bulloides umbilicata are abundant in the upper half of the hole. But Neogloboquadrina pachyderma forma $\mathrm{A}$ is generally abundant in the lower part of the hole and gradually decreases upward. Dextrally coiled specimens of $N$. pachyderma (s.s.), a cold-to-temperate-water form, occur in four intervals in Sections 478-36-4 and 478-36, CC, 478-28,CC through 478-31-2, 478-19-6 through 478-21, CC and 4783-4 through 478-7-3. There are two distinct intervals of abundant warm-water species in Sections 478-7-6 through 478-10, CC and 478-1-1 through 478-3-4. Neogloboquadrina dutertrei blowi occurs in the lowest and upper sections of the hole. Pulleniatina obliquiloculata occurs sporadically throughout the hole and is dextrally coiled except for two samples in Sections 478-31-2 and 478-35-4. One specimen of Pulleniatina obliquiloculata is sinistrally coiled, but another is dextrally coiled in Section 478-31-2; one specimen of this species is sinistrally coiled in Section 478-35-4.

\section{SITE 479}

Table 3 and Figure 5 show the occurrence of planktonic foraminifers in Hole 479. There is a wide interval between Cores $479-28$ and $479-42$ where planktonic foraminifers are absent because of dissolution. There are also several other relatively wide gaps, which make it difficult to detect a continuous faunal change.

The fauna below Core $479-42$ is different from that above Core 479-28. This basal fauna consists chiefly of Globigerinita glutinata, Globigerinoides ruber ruber, $G$. ruber elongatus, Globigerina quinqueloba, and G. bulloides bulloides. Globigerinoides bollii, G. obliquus, and Globigerina sp. A also occur only in this interval. We found four specimens of Pulleniatina obliquiloculata in Sample 479-42,CC, and all are sinistrally coiled (Plate 2, Figs. 14, 15), indicating that the fauna is from the late Pliocene epoch.

In the upper half of Hole 479, Neogloboquadrina dutertrei dutertrei, $N$. dutertrei forma A, and Globigerina bulloides bulloides are predominant. Neogloboquadrina pachyderma forma B is abundant in the middle-upper part (Sections 479-6-3-479-17-1) of the upper section. Globigerina bulloides quadrilatera and $G$. bulloides umbilicata occur continually above Sections 47926-2 and 479-23-5, respectively. Neogloboquadrina pachyderma (s.s.) occurs in Sections 479-23-5 through 27-3 and 479-6-3 through 12-6 in the upper half of the hole.

\section{SITE 480}

Hole 480 was drilled using a hydraulic piston corer. Unusually well-preserved and undisturbed laminated diatomaceous mud was recovered. Unfortunately, foraminifers are not well preserved because of the strong dissolution effect under the depth condition of the present oxygen-minimum zone. Only seven core-catcher samples yielded planktonic foraminifers (Table 4, Fig. 6.).

Globigerina bulloides bulloides, $G$. bulloides quadrilatera, G. bulloides umbilicata, G. quinqueloba, and Globigerinita glutinata are abundant in most samples. Neogloboquadrina dutertrei forma $\mathrm{A}$ and $N$. pachyderma forma A and forma B are predominant in a few top samples. Warm-water species are abundant in the middle part of the hole (Sections 480-16,CC and 480$21, \mathrm{CC}$ ). Globigerina pachyderma (s.s.) occurs only at the top of the hole (Sections $480-3, C C$ and $480-4, C C$ ).

\section{SITE 481}

The section at Site 481 is a composite of Holes 481 (Cores 481-1-481-11) and 481A (Cores 481A-1-481A37). Table 5 and Figure 7 show the occurrence of planktonic foraminifers. There are two gaps in foraminiferal occurrence: Cores 481A-14 through 481A-17 and the part of the hole below Core 481A-31, where basaltic sills have intruded.

Globigerina bulloides bulloides and Neogloboquadrina dutertrei forma $\mathrm{A}$ are common throughout the section. Globigerinita glutinata and Neogloboquadrina pachyderma forma B are also abundant in many samples. Globigerina bulloides quadrilatera is abundant above Section 481A-12-1, and G. bulloides umbilicata is abundant above Section 481A-9-6. Neogloboquadrina pachyderma forma $\mathrm{A}$ is abundant in the middle section (Cores 481A-18-481A-22) and is less abundant upward in the hole. $N$. pachyderma (s.s.) occurs in three intervals: Sections 481A-18,CC through 481A-22-2, 481A6-4 through 481A-12-1, and 481-6,CC through 481A-4-3. Warm-water species occur rather continuously throughout the hole, and, except for an interval in Sections 481-3, CC through 481-7-2 and in a few other samples, their composite frequency is not high. $N$. dutertrei blowi occurs sporadically between Cores $481-8$ and $481 \mathrm{~A}-22$.

\section{CORRELATION WITHIN THE GUAYMAS BASIN}

Figure 8 shows the relation of the sites in the Guaymas Basin to the occurrence of selected planktonic foraminifers, including Globigerina bulloides quadrilatera, G. bulloides umbilicata, Neogloboquadrina dutertrei blowi, N. pachyderma forma A, N. pachyderma (s.s.), and some warm-water species.

The late Pliocene planktonic fauna in the basal part of Hole 479 do not occur in any other holes and seem to be the oldest fauna in the Basin. Except for this Pliocene fauna, there are no index species in the Quaternary sequence. Nevertheless, faunal variations of planktonic microfossils, caused by paleoclimatic and paleoceanographic changes, are usually very effective for correlation within Quaternary sediment. It is difficult, however, to make a precise correlation based on planktonic faunal changes, because there are several gaps in the planktonic foraminiferal record.

The most distinct and useful faunal data are the abundant and continuous occurrences of Globigerina bulloides quadrilatera and $G$. bulloides umbilicata in the upper half of the Quaternary sequence, although they are not distinct in Holes 479 and 480 because of several rather wide sample gaps. The first abundant and continuous occurrences of Globigerina bulloides quadrilatera and $G$. bulloides umbilicata are shown in Figure 8 with the correlation horizons $\mathrm{C}$ and $\mathrm{B}$, respectively. Horizon A indicates the last occurrence of Neogloboquadrina dutertrei blowi. Moreover, this horizon nearly corresponds to the last occurrence of the dextrally coiled 


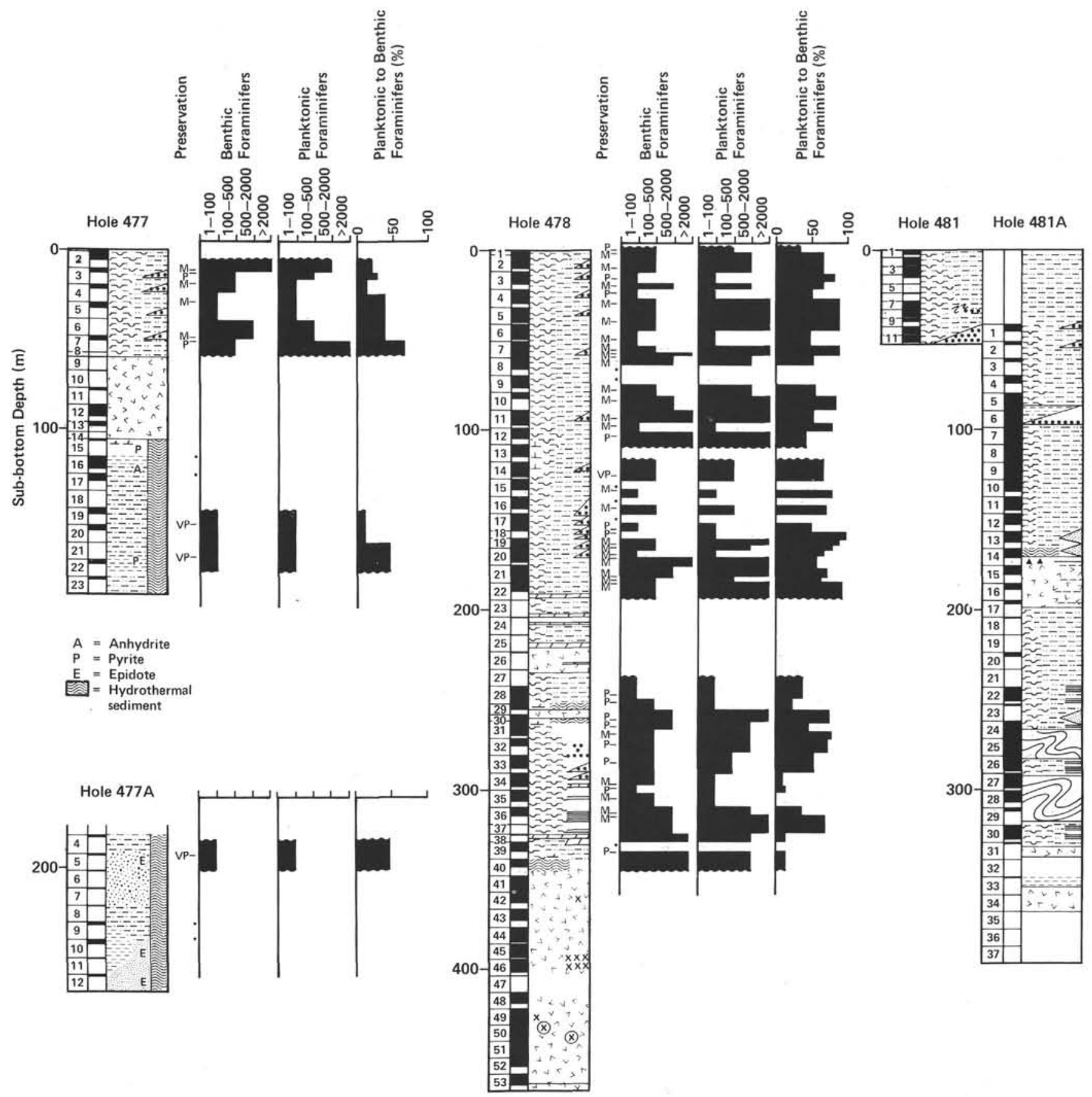

Figure 2. Preservation, abundance, and ratio of planktonic to benthic foraminifers, Guaymas Basin sites. (Preservation: $\mathrm{M}=$ moderate, $\mathrm{P}=$ poor, $\mathrm{VP}=$ very poor. Abundance was calculated for number of specimens per $10 \mathrm{ml}$ of sediment.)

form of Neogloboquadrina pachyderma (s.s.), and the warm-water species become abundant above this horizon. The interval between horizons $\mathrm{D}$ and $\mathrm{D}^{\prime}$ is characterized by abundant occurrences of Neogloboquadrina pachyderma forma $\mathrm{A}$ and $N$. pachyderma (s.s.); $N$. dutertrei blowi also occurs in this interval.

\section{GEOLOGIC AGE}

The oldest fauna we found in the Guaymas Basin is in the basal part of Hole 479. According to Blow (1969), Globigerinoides bollii ranges from his Planktonic Foraminiferal Zone, N11 to the upper part of Zone N21 (middle Miocene to Pliocene); G. obliquus ranges from Zone N6 to the lower part of Zone N22 (early Miocene to earliest Pleistocene). In the eastern equatorial Pacific, Jenkins and Orr (1972) recorded the range of G. bollii from the Globorotalia fohsi fohsi-G. peripheroacuta zone (N10-11) to the Sphaeroidinella dehiscens zone (N19-N20; middle Miocene to Pliocene) and G. obliquus from the Globigerinita dissimilis zone (N5-N6) to the lower Pulleniatina obliquiloculata zone (N22-N23; early Miocene to early Pleistocene). Parker (1967), in a study of tropical Indo-Pacific deep-sea cores, recorded the tops of the ranges of the two species at the basal part 


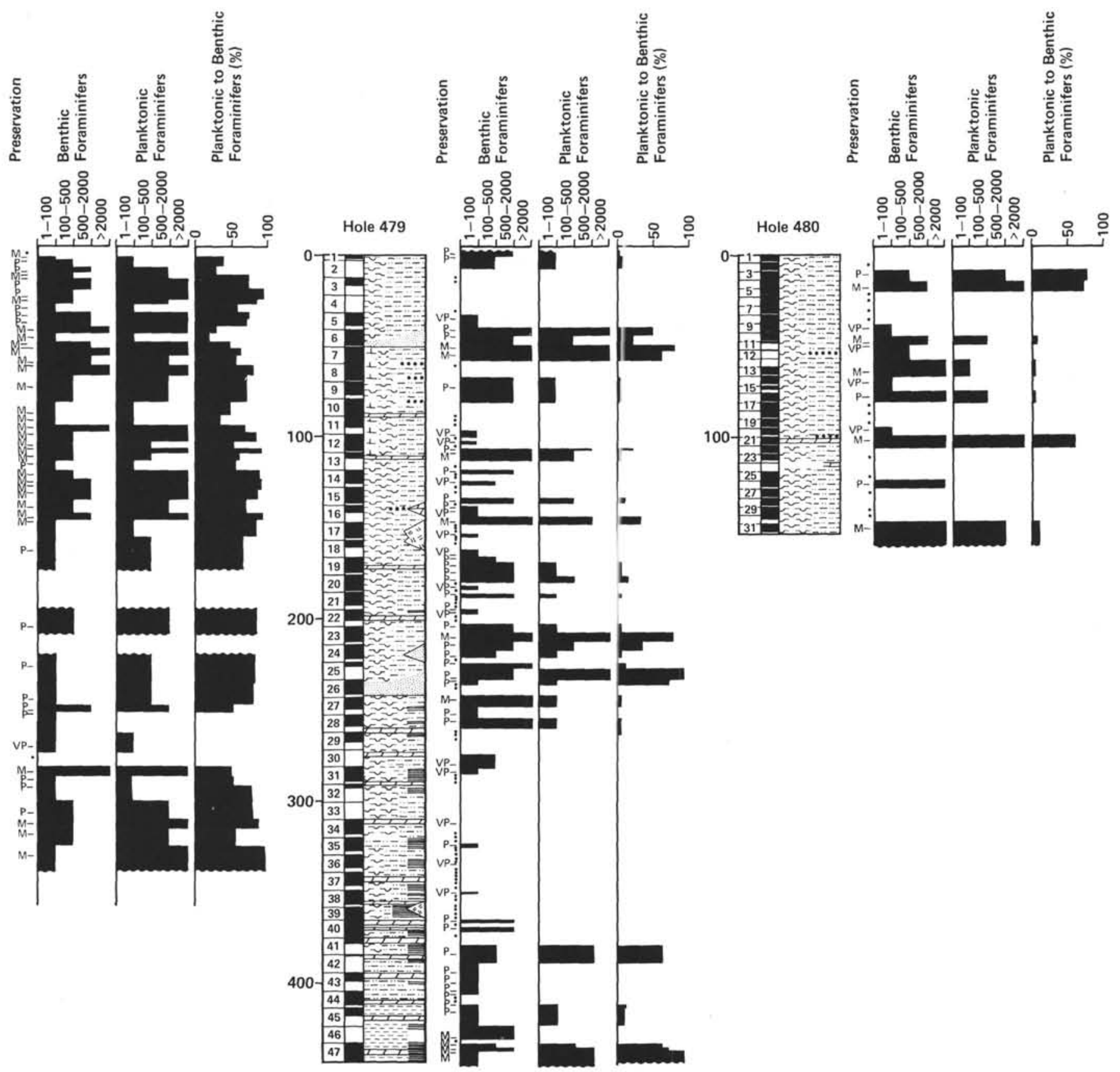

Figure 2. (Continued).

of Zone N21 as late Pliocene. But Brönnimann and Resig (1971) recorded the latest occurrences of the two species in N22 and N23, respectively, in the southwestern Pacific. Ingle (1974) reported on Globigerinoides obliquus from the Pliocene (N20-N21) Carmen Formation, Carmen Island, Gulf of California. Saito (1977) presented the extinction datum of $G$. obliquus at $1.76 \mathrm{Ma}$. Thompson and Sciarrillo (1978), on the basis of an examination of eight deep-sea cores from the equatorial Pacific (Fig. 9), proposed that the extinction datum of the species $(1.63 \mathrm{Ma})$ be placed near the Pliocene/Pleistocene boundary.
Sinistrally coiled Pulleniatina obliquiloculata occurs in Section 479-42, CC and in two samples from the basal part of Hole 478. According to Hays et al. (1969), Saito et al. (1975), Saito (1976, 1977), and Thompson and Sciarrillo (1978), the coiling direction of Pulleniatina changed several times after its first appearance in the earlier paleomagnetic (Epoch 5; 6.1 Ma), which appearance included at least four major left-coiling intervals. The patterns of the coiling changes in this species are c osely correlative within the Indo-Pacific regions. The occurrences of Globigerinoides bollii, G. obliquus, Pulleniatina obliquiloculata (s.s.) (middle Pliocene to Re- 
Table 1. Abundance and occurrence of planktonic foraminifers, Holes 477 and $477 \mathrm{~A}$.

\begin{tabular}{|c|c|c|c|c|c|c|c|c|c|}
\hline $\begin{array}{c}\text { Sample } \\
\text { (interval in } \mathrm{cm} \text { ) }\end{array}$ & $\begin{array}{l}\infty \\
0 \\
0 \\
\infty \\
\frac{1}{5} \\
\frac{1}{5}\end{array}$ & $\begin{array}{l}\frac{3}{1} \\
\frac{1}{0} \\
\frac{1}{2} \\
\frac{1}{5}\end{array}$ & $\begin{array}{l}\frac{9}{5} \\
\frac{1}{5} \\
\frac{1}{5} \\
\frac{5}{5}\end{array}$ & 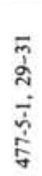 & $\begin{array}{l}\frac{2}{2} \\
\frac{1}{5} \\
\frac{5}{5} \\
\frac{5}{5}\end{array}$ & $\begin{array}{l}\frac{9}{1} \\
\frac{1}{2} \\
\frac{5}{5} \\
\frac{1}{5} \\
\frac{5}{7}\end{array}$ & 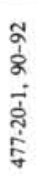 & 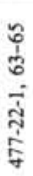 & 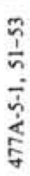 \\
\hline Globigerina bermudezi & & 3 & 3 & 4 & & 1 & & & \\
\hline G. bulloides bulloides & 43 & 39 & 28 & 22 & 40 & 43 & & & $\mathrm{x}$ \\
\hline G. bulloides quadrilatera & 6 & 6 & 5 & 7 & 4 & 3 & & & \\
\hline G. bulloides umbilicata & 7 & & 8 & 13 & 3 & 4 & & & \\
\hline G. falconensis & & 6 & 8 & & 6 & 5 & & & \\
\hline G. quinqueloba & & 3 & & 2 & 2 & & & & \\
\hline G. cf. quinqueloba & + & 3 & 3 & 2 & I & & & & \\
\hline G. rubescens & 1 & & & & & & & & \\
\hline G. spp. & & 1 & 3 & & 1 & & & & \\
\hline Globigerinita glutinata & 16 & 21 & 23 & 17 & 4 & 1 & & & $\mathrm{x}$ \\
\hline G. uvula & & & & & 3 & & & & \\
\hline Globigerinoides quadrilobatus sacculifer & & & & & & + & & & \\
\hline $\begin{array}{l}\text { G. quadrilobatus trilobus } \\
\text { G. ruber ruber }\end{array}$ & 1 & & & 4 & 4 & 4 & & & $\mathrm{x}$ \\
\hline G. tenellus & 2 & & & & & & & & \\
\hline G. sp. A & + & & & & & & & & \\
\hline Globorotalia cultrata & & & & 9 & 4 & 1 & & & + \\
\hline G. scitula & & & & 2 & & & & & \\
\hline Neogloboquadrina dutertrei blowi & & & & & 3 & 1 & & & \\
\hline N. dutertrei dutertrei & + & & & & & & & & \\
\hline N. dutertrei forma A & 13 & 7 & 3 & 4 & 14 & 12 & & & \\
\hline N. pachyderma (s.s.) & & & & & 2 & 1 & & & \\
\hline N. pachyderma forma $\mathrm{A}$ & & & 10 & & 3 & 2 & & & \\
\hline N. pachyderma forma B & 9 & 10 & 10 & 9 & 6 & 3 & $\mathrm{x}$ & & \\
\hline $\begin{array}{l}\text { N. spp. } \\
\text { Orbulina universa }\end{array}$ & + & & & & & + & & & $\begin{array}{l}\mathrm{X} \\
\mathrm{X}\end{array}$ \\
\hline Pulleniatina obliquiloculata & 1 & 1 & & 4 & 1 & & & & $\mathrm{x}$ \\
\hline $\begin{array}{l}\text { Turborotalita guaymasensis n. sp. } \\
T \text {. spp. }\end{array}$ & & & & & 1 & & & & \\
\hline Miscellaneous & & & & & & 16 & & $\mathrm{X}$ & $\mathrm{x}$ \\
\hline Total number examined & $\frac{n}{i}$ & $\bar{F}$ & $q$ & f & $\cong$ & ๙ิ & $n$ & $\vartheta$ & $\simeq$ \\
\hline
\end{tabular}

Note: Abundance is recorded as a percentage of total planktonic specimens counted $(+=$ $<1 \%$ ). Percentages were not calculated for samples containing less than 30 specimens ( $\mathrm{X}=$ presence of the taxon in the sample).

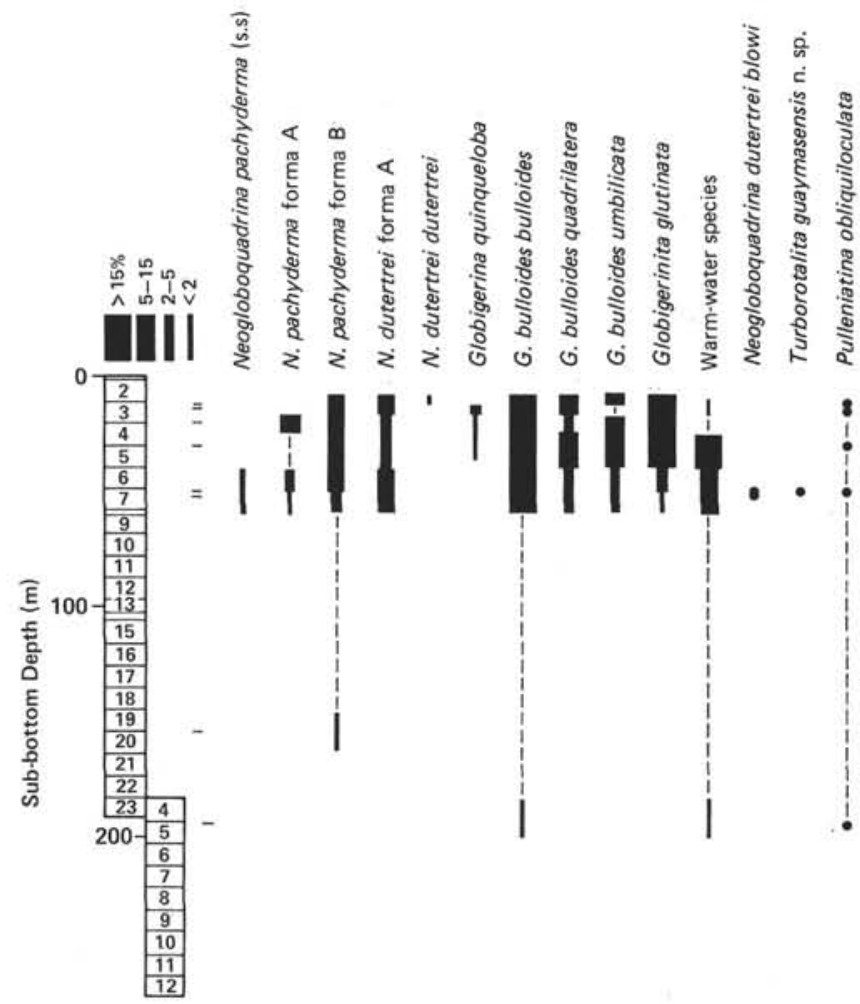

Figure 3. Stratigraphic occurrence of selected planktonic foraminifers, Site 477 . (Solid circle denotes only the taxon's presence in a sample.) cent; Blow, 1969), Neogloboquadrina dutertrei blowi (late Pliocene to Recent; Blow, 1969), and Globigerinoides tenellus (early Pleistocene to Recent; Blow, 1969) indicate that the basal fauna of Hole 479 (Sections 479$42, \mathrm{CC}-479-47, \mathrm{CC})$ is latest Pliocene, and that the sinistral Pulleniatina obliquiloculata population in Section 479-42,CC may be correlated with the sinistral interval (numbered L5 or L6 in Fig. 9; Saito, 1976; Thompson and Sciarrillo, 1978) near the Olduvai Event of the Matuyama Reversed Epoch of the upper part of Zone N21. The coiling change of Pulleniatina is also evident and correlates with the middle latitude of the northwestern Pacific, where the warm Kuroshio Current flows northeastward (Matoba, 1967; Oda, 1977).

There are several studies of the late Cenozoic planktonic foraminiferal fauna off the west coast of North America (Bandy and Ingle, 1970; Olsson, 1971; Ingle, 1973a, 1973b, 1977a, 1977b; Keller, 1978a, 1978b, 1979a, 1979b). It is difficult, though, to correlate these studies with the Quaternary sequence of the Guaymas Basin, because characteristic species and faunal events in the Basin sequence are scarce, partly because of the special paleoceanographic conditions of the Gulf. Almost all variant specimens of Neogloboquadrina pachyderma in the Guaymas Basin holes are dextrally coiled, and the coiling change of the species-an important means of correlation in the northeastern Pacific-is of no use for this study.

Keller (1978a, 1978b, 1979b) distinguished three morphotypes within $N$. pachyderma in central and eastern North Pacific deep-sea cores and recorded the paleoceanographic oscillations during the Pliocene to Pleistocene epochs in the middle latitudes. As the morphologic variation of the species in the Pleistocene Guaymas Basin seems to be somewhat different from that of the California Current, our morphotypes may differ from Keller's. As we will discuss later, our $N$. pachyderma (s.s.) may correspond approximately to Keller's $N$. pachyderma form 1 and our forma A to Keller's form 2 . Keller's $N$. pachyderma form 3 may be included in our $N$. dutertrei blowi. She found two horizons of N. pachyderma form 3 with form 2 in the middle part of the Pleistocene sequence at DSDP Site 173; she dated the two horizons 0.7 and $0.92 \mathrm{Ma}$, respectively (Keller, $1979 \mathrm{~b})$. Judging from the abundant and continuous occurrence of $N$. pachyderma forma A with $N$. dutertrei blowi at the interval $\mathrm{D}^{-\mathrm{D}^{\prime}}$ and the tendency of $N$. pachyderma forma A to decrease upward in the Guaymas Basin, we can approximately correlate the interval with the two horizons of $N$. pachyderma form 3 (Pleistocene) in Hole 173. The abundant and continuous occurrence of Globigerina bulloides quadrilatera and $G$. bulloides umbilicata above this interval also correlates with Hole 173. This correlation seems to be supported by the rare but significant occurrence of sinistrally coiled Pulleniatina obliquiloculata, suggesting that the interval can be correlated with the upper part of the Matuyama Reversed Epoch (Fig. 9). Horizon A, which is defined by the disappearance of Neogloboquadrina dutertrei blowi, seems approximately to correspond with the Pleistocene/Holocene boundary in the Guaymas Basin. Neogloboquadrina pachyderma (s.s.) nearly 
Table 2. Abundance and occurrence of planktonic foraminifers, Hole 478.

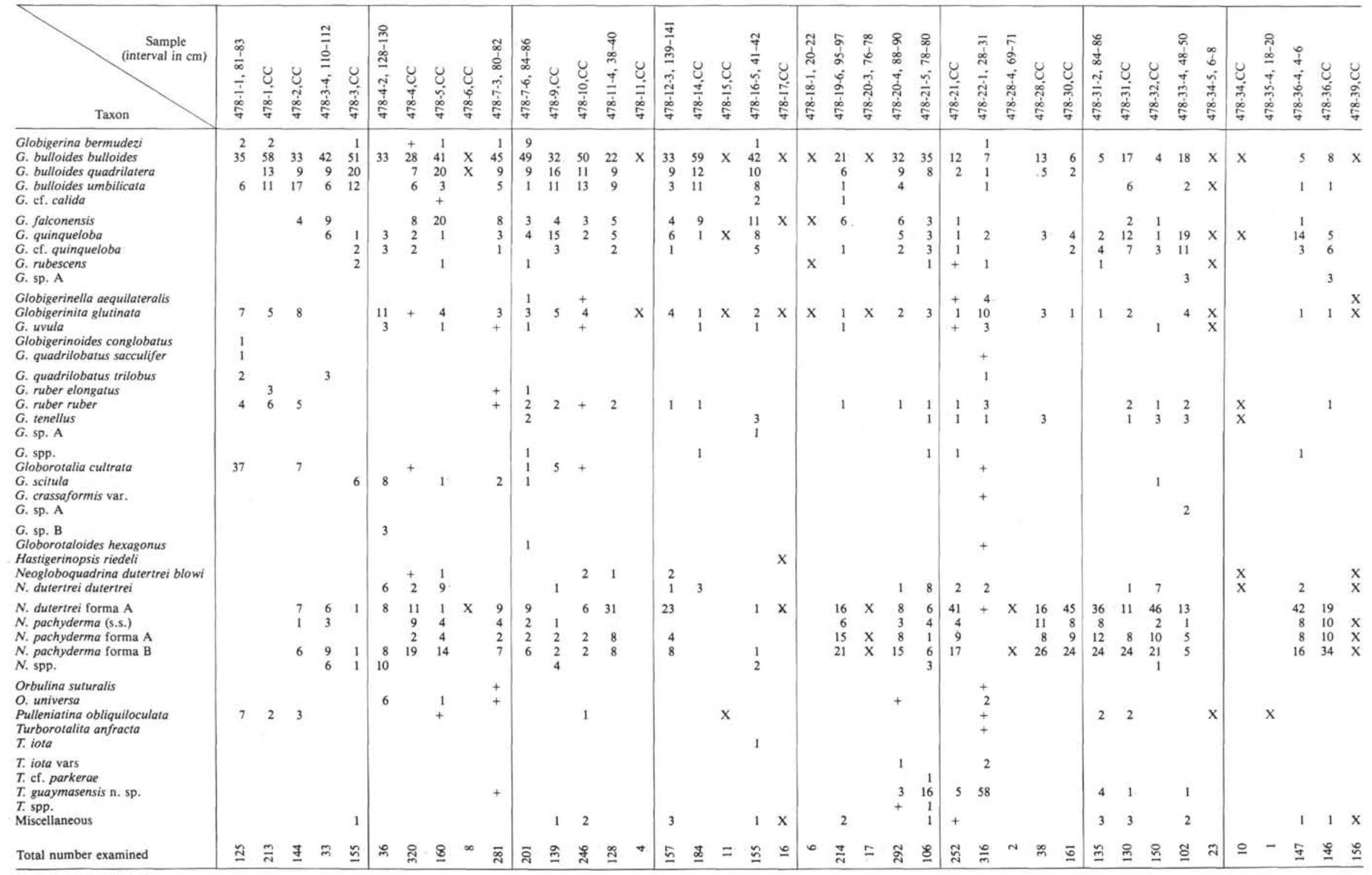

Nole: see note Table 


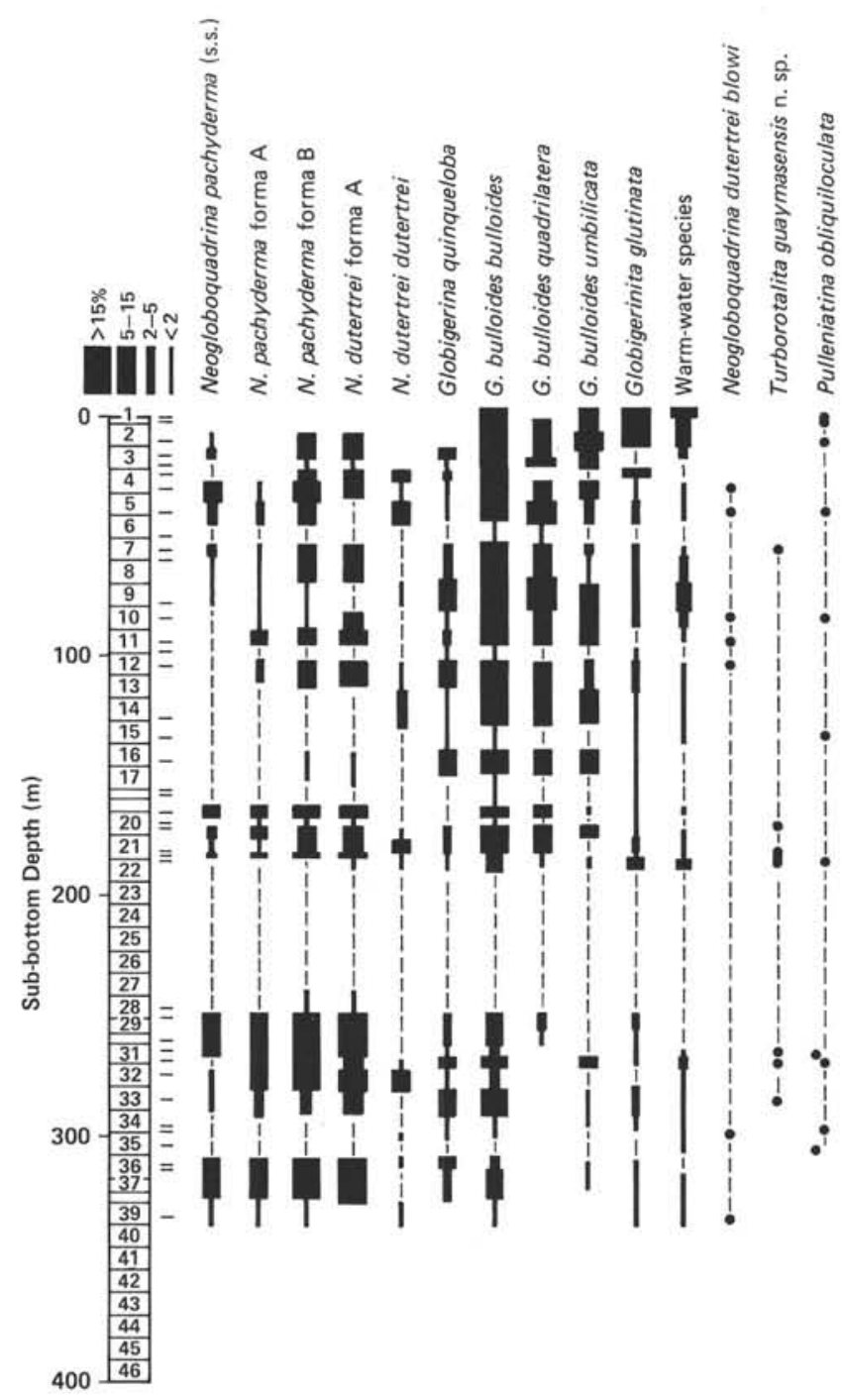

Figure 4. Stratigraphic occurrence of selected planktonic foraminifers, Site 478. (Solid circle denotes only the taxon's presence in a sample.)

disappears at this horizon, and warm-water species become abundant, indicating the relatively warmer-water condition of the interval above this horizon (Fig. 10).

Although planktonic foraminiferal evidence is lacking for the interval between Cores 479-29 through 47941 (just above the upper Pliocene sequence), Schrader (this volume) recorded Mesocena elliptica (silicoflagellate) and placed its extinction datum at around $0.7 \mathrm{Ma}$ for Section 479-32, CC and the Pleistocene first-occurrence datum at $0.93 \mathrm{Ma}$ for Section 479-39,CC. This suggests an unconformity between Cores 479-39 and 479-42. On the other hand, the late Pliocene benthic foraminiferal fauna extends upward to Sample 479-40$3,43-45 \mathrm{~cm}$ (Matoba and Yamaguchi, this volume). The possible unconformity, therefore, is limited to the upper part of Core 479-40. Based on the reflection profile passing near Hole 479 (Moore, 1973), an unconformity has been suggested for this depth. Our age assignment implies that the late Pliocene sediment at the basal part of Hole 479 belongs to the proto-Gulf of California sequence defined on the reflection profiles (Moore, 1973).

\section{LATE CENOZOIC PALEOCEANOGRAPHY IN THE GULF OF CALIFORNIA}

Magnetic-anomaly profiles indicate that the present phase of spreading in the Gulf of California probably began about $4 \mathrm{Ma}$ in the early Pliocene (Larson et al., 1968). Prior to that, a proto-Gulf of California probably existed during the early to middle Miocene and early Pliocene epochs (Moore and Buffington, 1968; Karig and Jensky, 1972; Moore, 1973). Smith (1970) reported on a shallow-marine Pliocene foraminiferal fauna from the Bouse Formation along the lower Colorado River. Ingle $(1973,1974)$ recorded an upper bathyal foraminiferal fauna in the basal part of Pliocene (N19-21) Imperial Formation, Imperial County, California. Ingle (1974) also reported on a late Miocene (N16) planktonic foraminiferal fauna and an upper bathyal benthic fauna in a diatomite bed near San $\mathrm{Fe}$ lipe, Baja California, in the innermost part of the Gulf. $\mathrm{He}$ also suggested the possibility of a middle or even early Miocene initiation of the proto-Gulf. The seismic reflection profile in the Guaymas Basin, passing near Site 479 , indicates that the proto-Gulf sediment is overlain with an angular unconformity of younger, nearly 400-meter-thick sediment (Moore, 1973). Siltstone, dredged from the faulted northeast wall of the Guaymas Basin, contains Miocene or early Pliocene planktonic foraminifers (Moore, 1973).

The latest Pliocene sediment at the basal part of Hole 479 may belong to the proto-Gulf sequence of Moore (1973). The late Pliocene planktonic foraminiferal fauna is similar to that of the upper Pliocene (predominantly Globigerinoides) on Carmen Island (Ingle, 1974). The unconformity may have been formed in the early Pleistocene epoch, during the course of the present phase of spreading, rather than during the initiation of spreading as described by Moore (1973). The unconformity between the upper Pliocene sediment that contains bathyal benthic foraminiferal fauna and the shallow Pleistocene marine deposits exposed on Carmen Island (Natland, 1950; Ingle, 1974) also indicates that the early Pleistocene tectonism caused a vertical movement of at least a few hundred meters in parts of the Gulf. The depth preference of the benthic foraminiferal fauna of the upper Pliocene interval at Site 479 is almost the same as the faunas in the Quaternary sequence above it. The surface water in late Pliocene was warmer than was indicated by the Quaternary sequence in the Guaymas Basin (Fig. 10).

The occurrence of the colder-water, dextrally coiled Neogloboquadrina pachyderma (s.s.) and the frequent occurrence of relatively colder forms of $N$. pachyderma forma B and A are evidence for three cooler intervals in the middle to upper Pleistocene sequence of the Basin. They occur in the interval D-D', near the interval B-C, and in the upper part of the interval A-B (Fig. 10). Keller (1978a, 1978b, 1979a, 1979b) recorded two distinct cold intervals: a short interval in the lower Pleistocene and a long interval in the upper Pleistocene (Ingle's glacial Pleistocene [1973b]). Some fluctuations of warm and cold, as evidenced by the coiling ratios of Neogloboquadrina pachyderma and associated morphotypes, also occur in the middle Pleistocene sequence of 
Table 3. Abundance and occurrence of planktonic foraminifers, Hole 479.

\begin{tabular}{|c|c|c|c|c|c|c|c|c|c|c|c|c|c|c|c|c|c|c|c|c|c|c|c|c|c|c|c|c|c|c|}
\hline Taxon & $\begin{array}{l}5 \\
\vdots \\
\alpha \\
\vdots \\
\frac{1}{2} \\
\frac{1}{4}\end{array}$ & $\frac{u}{\frac{0}{j}}$ & 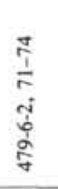 & 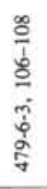 & 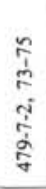 & 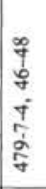 & 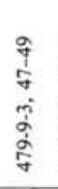 & 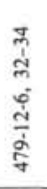 & 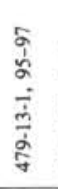 & $\begin{array}{l}\frac{1}{0} \\
\frac{1}{5} \\
\frac{5}{2} \\
\frac{4}{2}\end{array}$ & $\begin{array}{l}\frac{\infty}{1} \\
\stackrel{1}{1} \\
\frac{1}{2} \\
\frac{1}{4}\end{array}$ & $\begin{array}{l}\frac{0}{1} \\
\frac{1}{m} \\
\dot{1} \\
\frac{1}{2} \\
\dot{\alpha} \\
\dot{+}\end{array}$ & 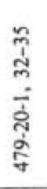 & 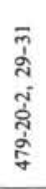 & $\begin{array}{l}\frac{4}{2} \\
\frac{7}{4} \\
\frac{y}{2}\end{array}$ & 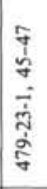 & 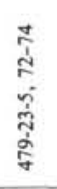 & 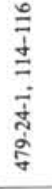 & 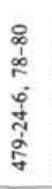 & 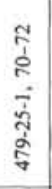 & 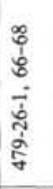 & 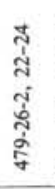 & 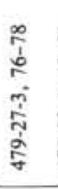 & 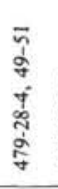 & 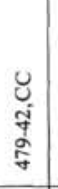 & 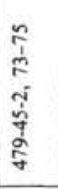 & 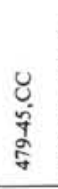 & 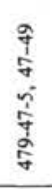 & 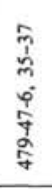 & 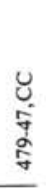 \\
\hline $\begin{array}{l}\text { lobigerina bermudezi } \\
\text { bulloides bulloides } \\
\text { bulloides quadrilatera } \\
\text { bulloides umbilicata } \\
\text { falconensis }\end{array}$ & 28 & $x$ & $\begin{array}{r}40 \\
4 \\
12 \\
2\end{array}$ & $\begin{array}{l}1 \\
1\end{array}$ & $\begin{array}{r}1 \\
19 \\
4 \\
3\end{array}$ & $\begin{array}{r}15 \\
7 \\
4 \\
4\end{array}$ & & $\begin{array}{l}3 \\
2\end{array}$ & $\begin{array}{r}16 \\
10 \\
1 \\
4\end{array}$ & $\begin{array}{l}7 \\
3\end{array}$ & $\begin{array}{r}2 \\
11 \\
4 \\
2 \\
1\end{array}$ & & $x$ & $\begin{array}{l}7 \\
5 \\
3 \\
1\end{array}$ & & & $\begin{array}{l}1 \\
3 \\
1 \\
1\end{array}$ & 2 & & $\begin{array}{l}1 \\
4\end{array}$ & 1 & 2 & & & + & & & 5 & $\begin{array}{r}1 \\
15 \\
2\end{array}$ & $\begin{array}{l}1 \\
+ \\
+\end{array}$ \\
\hline $\begin{array}{l}\text { G. quinqueloba } \\
\text { G. cf. quinqueloba } \\
\text { G. rubescens } \\
\text { G. sp. A } \\
\text { G. spp. }\end{array}$ & $\begin{array}{l}3 \\
3\end{array}$ & & $\begin{array}{l}6 \\
2 \\
3\end{array}$ & & $\begin{array}{l}2 \\
1\end{array}$ & $\begin{array}{l}2 \\
2 \\
1 \\
2\end{array}$ & & $\begin{array}{l}3 \\
2\end{array}$ & 2 & & $\begin{array}{l}30 \\
18\end{array}$ & $x$ & $x$ & & & 3 & $\begin{array}{l}1 \\
1\end{array}$ & & & & & & & & + & $x$ & $x$ & $\begin{array}{r}16 \\
3 \\
2 \\
3\end{array}$ & $\begin{array}{r}39 \\
9 \\
19\end{array}$ & $\begin{array}{r}5 \\
2 \\
1 \\
63\end{array}$ \\
\hline $\begin{array}{l}\text { Globigerinella aequilateralis } \\
\text { Globigerinita glutinata } \\
\text { G. uvula } \\
\text { Globigerinoides bollii } \\
\text { G. obliquus }\end{array}$ & 3 & & $\begin{array}{r}1 \\
10 \\
2\end{array}$ & & 1 & 2 & & 2 & $\begin{array}{r}1 \\
23 \\
2\end{array}$ & & 2 & & $\mathrm{x}$ & $\begin{array}{l}4 \\
8 \\
1\end{array}$ & & $\begin{array}{l}5 \\
1\end{array}$ & 2 & & & 1 & 1 & & & & $\begin{array}{r}69 \\
1\end{array}$ & & $x$ & $\begin{array}{l}6 \\
2 \\
3\end{array}$ & $\begin{array}{l}6 \\
1\end{array}$ & $\begin{array}{r}18 \\
2 \\
1\end{array}$ \\
\hline $\begin{array}{l}\text { G. quadrilobatus quadrilobatus } \\
\text { G. quadrilobatus sacculifer } \\
\text { G. quadrilobatus trilobus } \\
\text { G. ruber elongatus } \\
\text { G. ruber ruber }\end{array}$ & & & $\begin{array}{l}\frac{1}{2} \\
2\end{array}$ & 1 & & & & 2 & 2 & & 2 & & & $\begin{array}{l}7 \\
8 \\
7\end{array}$ & & & & & & & & & & & $\begin{array}{l}11 \\
15\end{array}$ & & $x$ & $\begin{array}{l}30 \\
24\end{array}$ & 1 & $\begin{array}{l}4 \\
1\end{array}$ \\
\hline $\begin{array}{l}\text { G. tenellus } \\
\text { G. spp. } \\
\text { Glaborotalia cultrata } \\
\text { G. scitula } \\
\text { G. tumida }\end{array}$ & 42 & $x$ & 3 & & & 2 & & 5 & 1 & & 1 & & $\mathrm{x}$ & 4 & & & & & & 1 & & & & & 2 & & & & & \\
\hline $\begin{array}{l}\text { Hastigerinopsis riedeli } \\
\text { Neogloboquadrina dutertrei blowi } \\
\text { N. dutertrei dutertrei } \\
\text { N. dutertrei forma A } \\
\text { N. pachyderma (s.s.) }\end{array}$ & & $x$ & 2 & $\begin{array}{r}26 \\
29 \\
8\end{array}$ & $\begin{array}{r}1 \\
36 \\
3\end{array}$ & $\begin{array}{r}2 \\
2 \\
37 \\
4\end{array}$ & $\mathrm{x}$ & $\begin{array}{r}1 \\
7 \\
26 \\
3\end{array}$ & $\begin{array}{l}2 \\
1\end{array}$ & $\begin{array}{r}3 \\
60 \\
7 \\
1\end{array}$ & 15 & & $x$ & $\begin{array}{r}10 \\
10 \\
4\end{array}$ & X & $\begin{array}{l}3 \\
8\end{array}$ & $\begin{array}{r}1 \\
5 \\
36 \\
11\end{array}$ & $\begin{array}{l}7 \\
13 \\
12\end{array}$ & $x$ & $\begin{array}{l}71 \\
18\end{array}$ & $\begin{array}{r}6 \\
19 \\
24 \\
5\end{array}$ & 94 & $\begin{array}{r}6 \\
46 \\
3\end{array}$ & $x$ & & & & 2 & $\begin{array}{l}1 \\
2 \\
2 \\
3\end{array}$ & 1 \\
\hline $\begin{array}{l}\text { N. pachyderma forma A } \\
N \text {. pachyderma forma B } \\
N \text {, spp. } \\
\text { Orbulina suturalis } \\
\text { O. universa }\end{array}$ & & $\begin{array}{l}x \\
x\end{array}$ & $\begin{array}{l}1 \\
1\end{array}$ & $\begin{array}{l}17 \\
18\end{array}$ & $\begin{array}{l}5 \\
7\end{array}$ & $\begin{array}{r}5 \\
10\end{array}$ & $\mathrm{x}$ & $\begin{array}{l}12 \\
33\end{array}$ & 1 & $\begin{array}{r}7 \\
12\end{array}$ & 4 & & $\begin{array}{l}x \\
x\end{array}$ & 2 & $x$ & $\begin{array}{l}33 \\
51\end{array}$ & $\begin{array}{r}8 \\
29\end{array}$ & $\begin{array}{c}7 \\
56\end{array}$ & & 3 & $\begin{array}{l}13 \\
25\end{array}$ & 4 & $\begin{array}{r}9 \\
37\end{array}$ & & & & & $\begin{array}{l}4 \\
1\end{array}$ & & \\
\hline $\begin{array}{l}\text { Pulleniatina obliquiloculata } \\
\text { Turborotalita iota } \\
\text { T. iota vars. } \\
\text { T. cf. parkerae } \\
\text { T. guaymasensis } \mathrm{n} \text {. sp. } \\
\text { T. spp. } \\
\text { Miscellaneous }\end{array}$ & 25 & $\mathrm{x}$ & $\begin{array}{l}2 \\
2 \\
3\end{array}$ & 1 & 18 & 5 & & 1 & 32 & & 5 & & $x$ & 2 & & & & & & & 1 & & & & 2 & & & & 1 & 1 \\
\hline Total number examined & 禺 & I & $\Xi$ & $\stackrel{8}{0}$ & లొ & $\cong$ & $\infty$ & $\equiv$ & $\infty$ & $\bar{\infty}$ & ‡ & - & స & 8 & 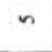 & बे & 告 & $\tilde{\infty}$ & 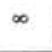 & $\stackrel{\infty}{\sim}$ & d & F & $\approx$ & $\simeq$ & $\tilde{\aleph}$ & - & 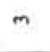 & $\cong$ & $\Xi$ & సે \\
\hline
\end{tabular}

Note: See note, Table 1.

DSDP Hole 173 off northern California under the California Current. The latest Pliocene through earliest Pleistocene epochs were distinctly warm, and the early through middle Pleistocene was generally warm except for the interval already mentioned. The lower Pleistocene faunal evidence, including the lower, short, cold event, is lacking in the Guaymas Basin sequence. The middle Pleistocene variations in Hole 173 are correlated with the interval D- $\mathrm{D}^{\prime}$ in the Guaymas Basin. The distinct, long, cold interval in the later half of Pleistocene sequence of Hole 173 cannot be recognized in the Guaymas Basin sequence, where two separate and cooler events are recorded. Thus, the Pleistocene climatic fluctuation patterns-as indicated by planktonic foraminifers-off northern California are quite different from those of the central Gulf of California.

The water character in the Gulf of California may have been primarily governed by the prevailing water masses at the entrance of the Gulf. Planktonic foraminifers, which are essentially oceanic, were introduced into the Gulf with these water masses. The present Gulf of
California is at a critical location: The cool California Current flows southeastward toward the entrance of the Gulf, where it converges with the equatorial water. The Pleistocene climatic oscillation resulted in shifts of the convergence to the north and to the south, and such an oceanographic condition existed throughout the Neogene epoch (Ingle, 1973a, 1973b, 1977a, 1977b). Ingle (1973b, 1974) noted that a subarctic fauna invaded the Gulf of California during the glacial Pleistocene epoch and was trapped by the northward readjustment of isotherms in the Holocene epoch. This may have occurred not only during the glacial Pleistocene-to-Holocene transition, but also during the preceding similar transitions from cold to warm periods. Such a special geographic situation in the Gulf of California may have caused the different oceanographic records and the different climatic fluctuation patterns recorded by planktonic foraminiferal fauna between the Gulf of California and the open, northeastern Pacific. The benthic foraminiferal faunas also indicate that the water character or the depths of the oxygen-minimum zone changed 


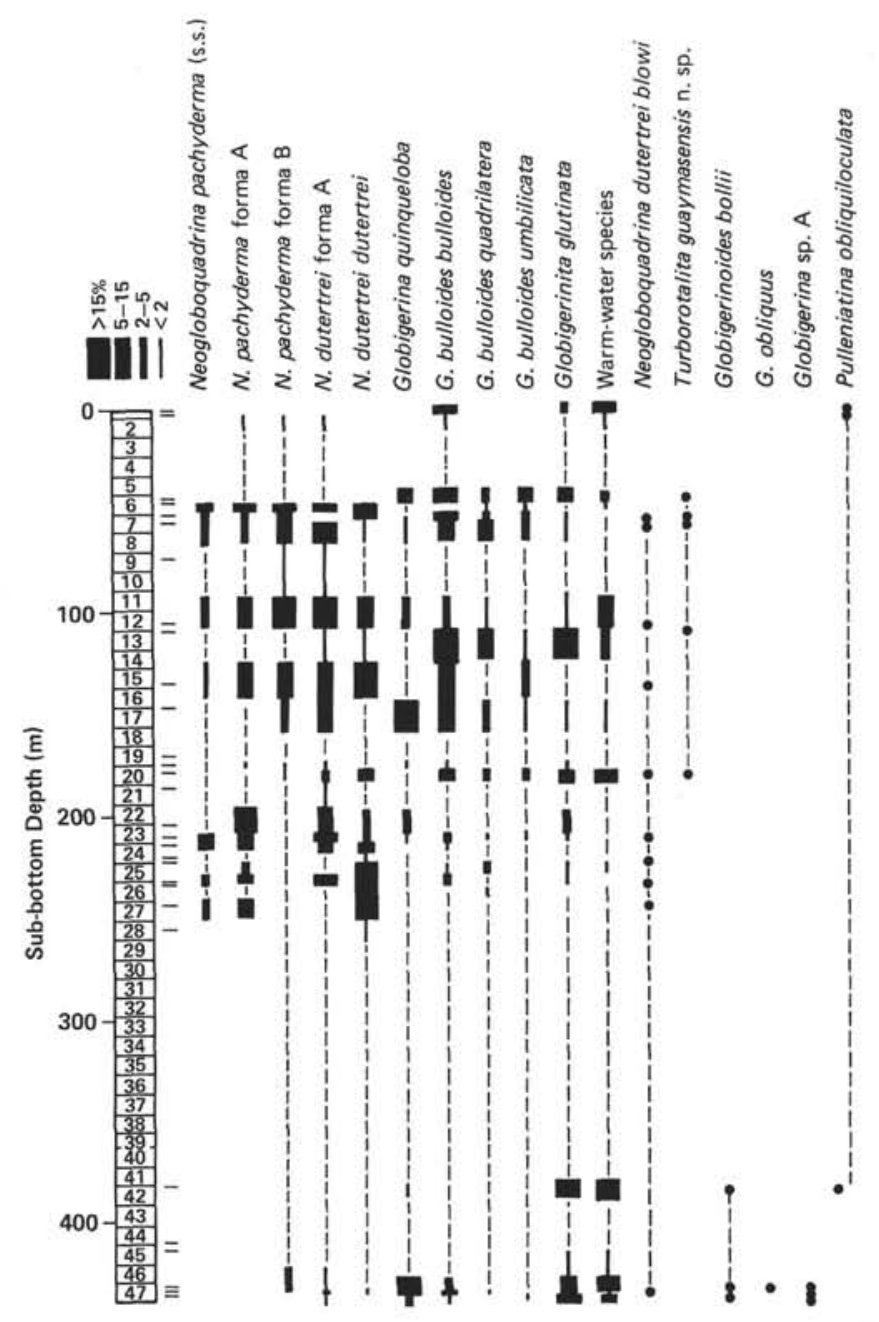

Figure 5. Stratigraphic occurrence of selected planktonic foraminifers, Site 479. (Solid circle denotes only the taxon's presence in a sample.)

during the Pleistocene epoch (Matoba and Yamaguchi, this volume).

\section{FAUNAL REFERENCE LIST}

Listed herewith are the species, subspecies, and morphotypes of planktonic foraminifers at Sites 477 through 481 . We give the original references for all named taxa, a few subsequent references, and brief remarks for some. Most of the taxa are illustrated in Plates 1 through 5 by scanning electron microphotographs (JSM-U3). All the types are catalogued and deposited in the Institute of Mining Geology, Mining College, Akita University, Akita, Japan (AKMG numbers), except for the holotype and figured paratypes of a new species.

Globigerina bermudezi Seiglie (Plate 1, Figs. 1A, 1B). Globigerina bermudezi Seiglie, 1963, p. 90, pl. 1, figs. 1-8. Rögl and Bolli, 1973 , p. 562, pl. 2, figs. 11-19, pl. 2, fig. 4. This species, characterized by the narrow and typically umbilical extension of the last few chambers, occurs sporadically at all the sites.

Globigerina bulloides bulloides d'Orbigny (Plate 1, Figs. 5, 6). Globigerina bulloides d'Orbigny, 1826, p. 277, no. 1 (no figure given; fide Ellis and Messina, 1940 et seq.). Brady, 1884, p. 593, pl. 79, figs. 7a-c. Banner and Blow, 1960, p. 3, pl. 1, figs. 1, 4 (lectotype). Globigerina bulloides (s.s.) is one of the predominant forms and occurs throughout the sequences at all the sites.

Globigerina bulloides quadrilatera Galloway and Wissler (Plate 1, Figs. 2A-C). Globigerina quadrilatera Galloway and Wissler, 1927 , p. 44, pl. 7, figs. 11a-c. A G. bulloides-like form with the diminutive final chamber is separated from $G$. bulloides (s.s.) and
Table 4. Abundance and occurrence of planktonic foraminifers, Hole 480 .

\begin{tabular}{|c|c|c|c|c|c|c|c|}
\hline$\underbrace{\begin{array}{c}\text { Sample } \\
\text { (interval in cm) }\end{array}}_{\text {Taxon }}$ & 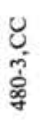 & 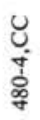 & 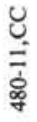 & 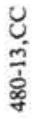 & $\begin{array}{l}u \\
\frac{u}{\delta} \\
\frac{\infty}{8}\end{array}$ & 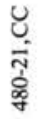 & $\frac{\dot{\theta}}{\frac{\tilde{n}}{\delta}}$ \\
\hline Globigerina bermudezi & & & & & 3 & 4 & 6 \\
\hline G. bulloides bulloides & & 13 & 31 & & 12 & 10 & 16 \\
\hline G. bulloides quadrilatera & & 5 & 7 & & 1 & 5 & 2 \\
\hline G. bulloides umbilicata & & 5 & 10 & & 7 & 10 & 4 \\
\hline G. falconensis & & 1 & & & 5 & 1 & 1 \\
\hline G. quinqueloba & & & 3 & & 8 & 28 & 37 \\
\hline G. cf. quinqueloba & & & & & 1 & 4 & 3 \\
\hline G. rubescens & & & & & & 3 & \\
\hline G. sp. B & & & & & 6 & 13 & 15 \\
\hline Globigerinella aequilateralis & & & & & & 3 & \\
\hline Globigerinita glutinata & & & 49 & & 21 & 12 & 5 \\
\hline G. uvula & & & & & 1 & & 1 \\
\hline Globigerinoides quadrilobatus quadrilobatus & & & & & 1 & & \\
\hline G. ruber elongatus & & & & & & 1 & \\
\hline G. ruber ruber & & & & & 28 & 5 & 1 \\
\hline G. tenellus & & & & & 1 & 1 & \\
\hline G. spp. & & 1 & & & & & \\
\hline Globorotalia cultrata & & 2 & & & & & \\
\hline Neogloboquadrina dutertrei blowi & & 5 & & & & & 2 \\
\hline N. dutertrei dutertrei & 10 & & & & & & 2 \\
\hline N. dutertrei forma A & 36 & 37 & & 56 & & & 6 \\
\hline N. pachyderma (s.s.) & 7 & 2 & & & & & \\
\hline N. pachyderma forma $\mathrm{A}$ & 24 & 11 & & 24 & & & \\
\hline N. pachyderma forma B & 22 & 19 & & 20 & & & 1 \\
\hline Pulleniatina obliquiloculata & & & & & & 1 & \\
\hline Turborotalita iota & & & & & 1 & & \\
\hline T. cf. parkerae & & & & & 1 & & \\
\hline T. guaymasensis n. sp. & & & & & & 1 & \\
\hline Total number examined & $\approx$ & ஓ్ల & $\infty$ & y & \& & ฮั่ & $\stackrel{\infty}{\simeq}$ \\
\hline
\end{tabular}

Note: See note, Table 1.

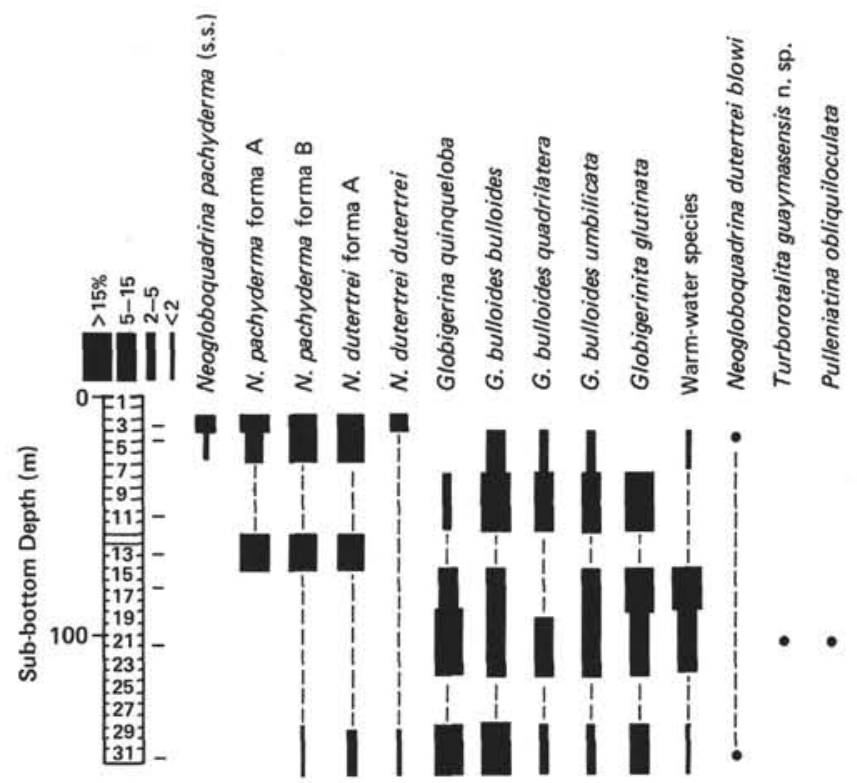

Figure 6. Stratigraphic occurrence of selected planktonic foraminifers, Site 480 . (Solid circle denotes only the taxon's presence in a sample.)

is treated as its subspecies. This subspecies is common at all the sites but is continuously abundant in the upper Pleistocene and Holocene sequence.

Globigerina bulloides umbilicata Orr and Zaitzeff (Plate 1, Figs. 3A-C, 4). G. umbilicata Orr and Zaitzeff, 1971, p. 18, pl. 1, figs. 1a-3c. Keller, 1978b, pl. 2, figs. 10, 11. Globigerina bulloides umbilicata Orr and Zaitzeff, Rögl and Bolli, 1973, p. 563, pl. 1, figs. 
Table 5. Abundance and occurrence of planktonic foraminifers, Holes 481 and 481A.

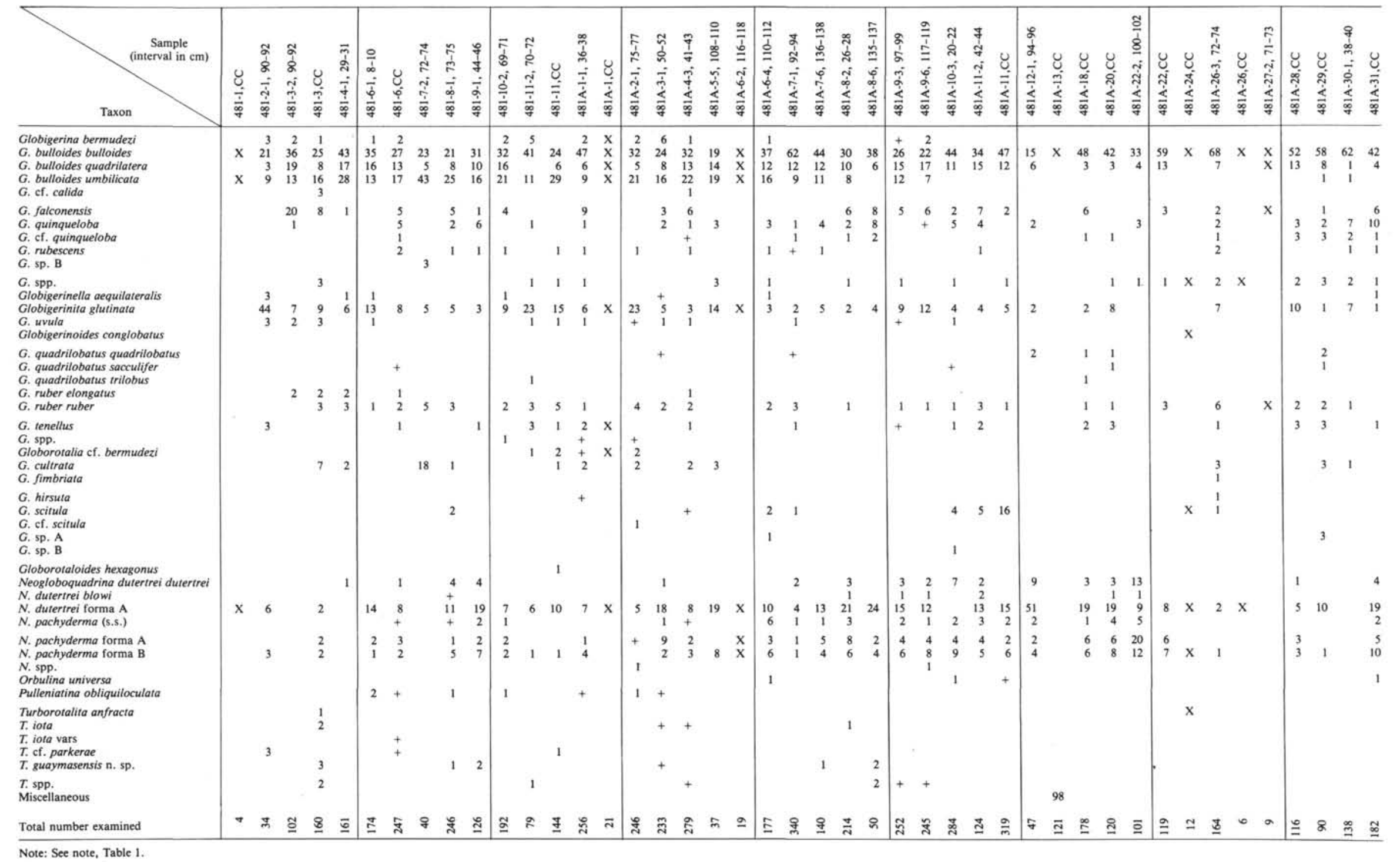




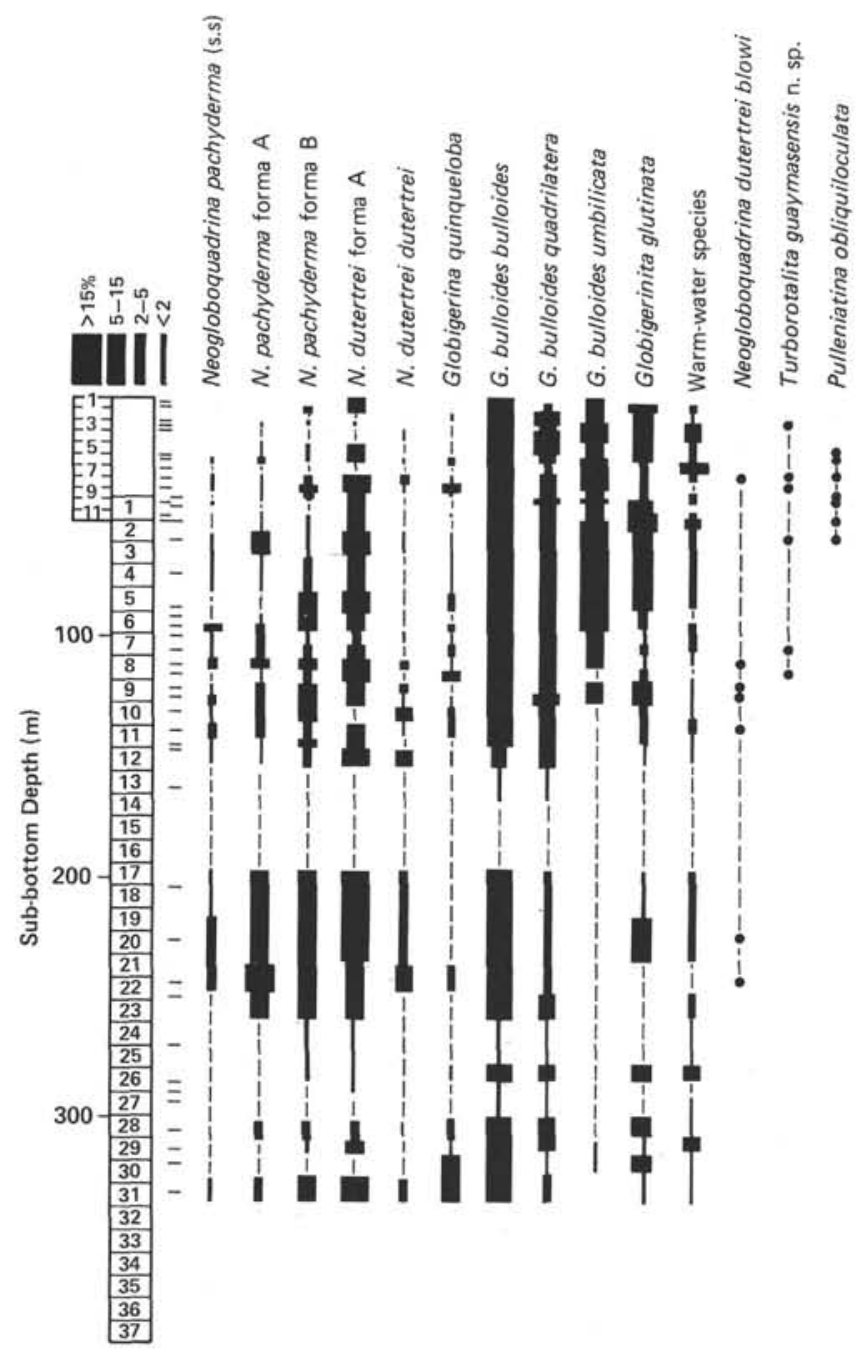

Figure 7. Stratigraphic occurrence of selected planktonic foraminifers, Site 481 . (Solid circle denotes only the taxon's presence in a sample.)

$19,20,22-24, \mathrm{pl} .11$, fig. 13 . This subspecies is characterized by a large umbilicus and the 5 to 6 large, well-developed chambers in the last whorl. It occurs at all the sites and is especially abundant in the upper Pleistocene to Holocene sequence above the horizon, somewhat higher than the horizon where $G$. bulloides quadrilatera becomes abundant.

Globigerina cf. G. calida Parker. Cf. Globigerina sp., Bradshaw, 1959 , p. 38 , pl. 6 , figs. $19,26-28$. Cf. G. Parker, 1962, p. 221, pl. 1 , figs. 9-13, 15. Some small or poorly preserved specimens are similar to this species.

Globigerina falconensis Blow (Plate 1, Fig. 10). Globigerina falconensis Blow, 1959, p. 177, pl. 9, figs. 40, 41. Parker, 1962, p. 224, pl. 1 , figs. 14, 16-19.

Globigerina quinqueloba Natland (Plate 1, Figs. 7A, B). Globigerina quinqueloba Natland, 1938, p. 149, pl. 6, fig. 7.

Globigerina cf. G. quinqueloba Natland (Plate 1, Figs. 8A, B). This form is similar to Globigerina quinqueloba, but the last chamber is spherical and does not extend over the umbilicus, which is open and deep. This form is associated with G. quinqueloba and is rare in the sequences at all the sites.

Globiginera rubescens Hofker (Plate 1, Fig. 11). Globigerina rubescens Hofker, 1956, p. 234, pl. 35, fig. 18-21 (fide Ellis and Messina, 1940 et seq.).

Globigerina sp. A (Plate 1, Figs. 12A-C). This species is very similar to Globigerina quinqueloba but has a thicker, tightly coiled test with a less lobulate equatorial periphery and 4 chambers instead of
5 in the final whorl. It occurs only in the late Pliocene samples in the basal sequence of Hole 479 .

Globigerina sp. B (Plate 1, Figs. 13-17). This species resembles Globigerina quinqueloba but in the typical form has 6 chambers instead of 5 in the final whorl. The shape and position of the last chamber varies. The typical form has a globular last chamber with a wide lip, but some others have somewhat elongate or reduced and elongate last chambers and often have a higher spired, tightly coiled test with 5 chambers in the last whorl. This species is abundant only in three samples in the lower section of Hole 480. A few specimens from Section 481-7-2 are tentatively included in this species. All are late Pleistocene.

Globigerinella aequilateralis (Brady) (Plate 2, Fig. 11). Globigerina aequilateralis Brady, 1879, p. 285 (fide Ellis and Messina, 1940 et seq.). Brady, 1884 , p. 605 , pl. 80 , figs. $18-21$. This species is rare and occurs sporadically in the Quaternary sequence.

Globigerinita glutinata (Egger) (Plate 2, Fig. 12). Globigerina glutinata Egger, 1893, p. 371, pl. 13, figs. 19-21 (fide Ellis and Messina, 1940 et seq.).

Globigerinita uvula (Ehrenberg) (Plate 2, Fig. 13). Pylodexia uvula Ehrenberg, 1861, p. 276, 277, 308. Ehrenberg, 1873, pl. 2, figs. 24, 25 (fide Ellis and Messina, 1940 et seq.). Banner and Blow, 1960, p. 5, 6, pl. 3, fig. 3. Globigerina bradyi Wiesner, 1931, p. 133 (fide Ellis and Messina, 1940 et seq.). Banner and Blow, 1960, p. 5, 6, pl. 3, fig. 1 (lectotype).

Globigerinoides bollii Blow (Plate 2, Figs. 1A, B). Globigerinoides bollii Blow, 1959, p. 189, pl. 10, figs. 65a-c. This species, characterized by a small, almost circular primary aperture, occurs in three Pliocene samples in the basal section of Hole 479 .

Globigerinoides conglobatus (Brady) (Plate 2, Fig. 2). Globigerina conglobata Brady, 1879, p. 286 (fide Ellis and Messina, 1940 et seq.); Brady, 1884 , p. 603 , pl. 80 , figs. $1-5$, pl. 82 , fig. 5 . Banner and Blow, 1960, p. 6, 7, pl. 4, figs. 4a-c (lectotype).

Globigerinoides obliquus Bolli (Plate 2, Fig. 3). Globigerinoides obliquus Bolli, 1957, p. 113, pl. 25, figs. 9a-10c. A few specimens occur in one Pliocene sample in the basal sequence of Hole 479.

Globigerinoides quadrilobatus quadrilobatus (d'Orbigny) (Plate 2, Fig. 4). Globigerina quadrilobata d'Orbigny, 1846, p. 164, pl. 9, figs. 7-10. Banner and Blow, 1960, p. 17, 18, pl. 4, figs. 3a-c (lectotype).

Globigerinoides quadrilobatus sacculifer (Brady) (Plate 2, Figs. 5, 6). Globigerina sacculifera Brady, 1877, p. 535 (fide Ellis and Messina, 1940 et seq.). Brady, 1884, p. 604, pl. 80, figs. 11-17, pl. 82 , fig. 4. Banner and Blow, 1960, p. 21-24, pl. 4, figs. 1a, b (lectotype). A single specimen from Sample 479-47-6, 35-37 cm, with a few slightly fistular projections of the last chamber (Pl. 2, Fig. 6), was included in this species.

Globigerinoides quadrilobatus trilobus (Reuss). Globigerina triloba Reuss, 1850, p. 374, pl. 47, figs. 11a-d (fide Ellis and Messina et seq.),

Globigerinoides ruber ruber (d'Orbigny) (Plate 2, Fig. 7). Globigerina rubra d'Orbigny, 1839 , p. 82,83 , pl. 4 , figs. 12-14. Banner and Blow, 1960, p. 19-21, pl. 3, figs. 8a, b (lectotype). This species occurs rather frequently at all the sites but is abundant only in a few Pliocene samples.

Globigerinoides ruber elongatus (d'Orbigny) (Plate 2, Fig. 8). Globigerina elongata d'Orbigny, 1846, p. 277 (fide Ellis and Messina, 1940 et seq.). Banner and Blow, 1960, p. 12, 13, pl. 3, figs. 10a-c (lectotype). This subspecies is rare and occurs only sporadically but is abundant in a few late Pliocene samples from Hole 479.

Globigerinoides tenellus Parker (Plate 2, Figs. 9, 10). Globigerinoides tenella Parker, 1958, p. 280, pl. 6, figs. 7-11. G. tenellus Parker, Parker, 1962, p. 232, pl. 4, figs. 11, 12. This species is rare and occurs in many samples in the Pleistocene to Holocene sequence in all holes; it also occurs in 1 upper Pliocene sample from Hole 479.

Globorotalia cf. G. bermudezi Rogl and Bolli (Plate 3, Figs. 1A-C). Cf. Globorotalia bermudezi Rogl and Bolli, 1973, p. 567, 568, pl. 6 , figs. $16-20$, pl. 16 , figs. $1-3$, fig. 6 (text). This form resembles G. bermudezi but differs from it in having a more inflated last chamber and a more broadly rounded axial periphery. A few specimens (latest Pleistocene) occur in 5 samples from Holes 481 and 481A.

Globorotalia crassaformis (Galloway and Wissler) (Plate 3, Figs. $10 \mathrm{~A}-\mathrm{C})$. Globigerina crassaformis Galloway and Wissler, 1927, p. 
41, pl. 7, figs. 12a-c. Only one specimen was found in Sample $478-22-1,28-31 \mathrm{~cm}$.

Globorotalia cultrata (d'Orbigny) (Plate 3, Figs. 14, 15). Rotalina cultrata d'Orbigny, 1839, p. 76 (plate published separately, pl. 5, figs. 7-9). Banner and Blow, 1960, p. 30, pl. 6, figs. 2a-c (neotype). This species is rare and occurs sporadically in the Quaternary sequence at all the sites. It is abundant, though (perhaps because of selective dissolution) in a few samples from the uppermost sections of Holes 478 through 481 .

Globorotalia fimbriata (Brady) (Plate 3, Figs. 11A, B). Pulvinulina menardii (d'Orbigny) var. fimbriata Brady, 1884, p. 691, pl. 103, figs. 3a, b. Banner and Blow, 1960, p. 25, 26, pl. 5, figs. 2a, b (lectotype). One specimen from Sample $481 \mathrm{~A}-26-3,72-74 \mathrm{~cm}$ is identical to this species.

Globorotalia hirsuta (d'Orbigny). Rotalina hirsuta d'Orbigny, in Baker-Webb and Berthelot, 1839, p. 131, pl. 1, figs. 37-39 (fide Ellis and Messina, 1940 et seq.). A few small specimens in 2 samples from Hole 481A seem to be identical to this species.

Globorotalia scitula (Brady) (Plate 3, Figs. 2-4). Pulvinulina scitula Brady, 1882, p. 716 (fide Ellis and Messina, 1940 et seq.). Brady, 1884 , p. 693 , pl. 103 , figs. $7 \mathrm{a}-\mathrm{c}$ (as $P$. patagonica). Banner and Blow, 1960, p. 27, 28, pl. 5, figs. 5a-c (lectotype). This species is rare to common but occurs sporadically in the Quaternary sequence.

Globorotalia cf. G. scitula (Brady) (Plate 3, Figs. 5A-C, 6A-C). A few specimens assigned to this form differ from $G$. scitula in having an apertural flap extending toward the umbilicus. This form occurs only in Sample 481A-2-1, 75-77 cm.

Globorotalia tumida (Brady) (Plate 3, Figs. 12, 13). Pulvinulina menardii (d'Orbigny) var. tumida Brady, 1877, p. 535 (fide Ellis and Messina, 1940 et seq.). Brady, 1884, p. 692, pl. 103, figs. 4a-6 (as P. tumida). Banner and Blow, 1960, p. 26, 27, pl. 5, figs. 5a-c (lectotype). A few specimens of this species occur in 1 latest Pliocene sample from Hole 479.

Globorotalia sp. A (Plate 3, Figs. 7A-C). This form resembles Globorotalia bermudezi and $G$. cf. $G$. bermudezi (PI. 3, Figs. 1A-C) but differs in having a distinctly coarse wall texture. Some specimens assigned to this form occur in 3 samples from Holes 478 and $481 \mathrm{~A}$. Globorotalia sp. B ${ }^{3}$ (Plate 3, Figs. 8A-C, 9A-C). This species is nearly identical to Globorotalia sp. of Rögl and Bolli (1973, p. 569 , pl. 7, figs. 1-4) and is characterized by the high-spired test and coarsely perforate wall; it differs from the latter, though, in its dextrally coiled test. Some specimens of this form occur in 2 latest Pleistocene samples from Holes 478 and 481A.

Globorotaloides hexagonus (Natland) (Plate 2, Fig. 17). Globigerina hexagona Natland, 1938, p. 149, pl. 7, figs. 1a-c. Globoquadrina hexagona (Natland), Parker, 1962, p. 244, pl. 8, figs. 5-13. Globorotaloides hexagona hexagona (Natland), Blow, 1969, p. 373,374 . This species occurs only in 1 sample from Section 481-11,CC.

Hastigerinopsis riedeli (Rögl and Bolli). Hastigerinella riedeli $\mathrm{R} b \ddot{g l}$ and Bolli, 1973, p. 576, pl. 4, figs. 1-5, pl. 14, figs. 1-3, 5 (text). Two small specimens found in Section 478-17, CC and Sample $479-47-6,35-37 \mathrm{~cm}$ may be identical to this species.

Neogloboquadrina dutertrei dutertrei (d'Orbigny) (Plate 4, Figs. 1A, B). Globigerina dutertrei d'Orbigny, 1839, p. 84, (plate published separately, pl. 4, figs. 19-21). Banner and Blow, 1960, p. 11, pl. 2, figs. 1a-c (lectotype). As discussed by Rögl and Bolli (1973), Srinivasan and Kennett (1976), and Thompson (1976), there is much controversy among investigators about the taxonomic treatment of Globigerina dutertrei d'Orbigny. In this study, we divided this group into three forms: Neogloboquadrina dutertrei dutertrei, $N$. dutertrei blowi, and $N$. dutertrei forma A. The form assigned to $N$. dutertrei dutertrei has 5 chambers in the final whorl and an umbilical aperture. Large specimens with 6 to 7 chambers in the final whorl, however, were also tentatively included in $N$. dutertrei dutertrei. This is one of the most important constituents of the Quaternary sequence in the Guaymas Basin.

Neogloboquadrina dutertrei blowi Rögl and Bolli (Plate 4, Figs. 5-8). Neogloboquadrina dutertrei blowi Rögl and Bolli, 1973, p. 570, pl. 9, figs. 19-22, pl. 17, fig. 12. Globigerina subcretacea Chapman, ${ }^{3}$ Thompson (1980, p. 785, pl. 4, figs. 1-3) recently described this species as Globorotalia
wilesi.
1902, pl. 36, figs. 16a, b (fide Ellis and Messina, 1940 et seq.). Globorotalia (Turborotalia) subcretacea (Lomnicki), Blow, 1969, p. 392 , pl. 4 , figs. 18-20 (lectotype). This subspecies was introduced by Rögl and Bolli (1973) as a new name for Globigerina subcretacea Chapman, 1902 (not Lomnicki, 1901). It is characterized by a large, low trochospiral test with slightly more than 4 to 5 chambers in the final whorl and a flat or concave spiral side. The subspecies differs from $N$. dutertrei dutertrei in having an umbilical-extraumbilical aperture throughout ontogeny and from $N . d u$ tertrei pseudopima (Blow) in the wider umbilicus and more numerous chambers in the final whorl. This subspecies generally occurs in 4 intervals in the upper Pliocene to Pleistocene sequence in association with $N$. pachyderma forma $\mathrm{A}$ and almost disappears at the Pleistocene/Holocene boundary in the Guaymas Basin. A part of $N$. pachyderma form 3 of Keller (1978a, 1978b) may be included in this subspecies.

Neogloboquadrina dutertrei (d'Orbigny) forma A (Plate 4, Figs. 2-4). This form is trochospiral with 5 (or 6) chambers in the last whorl. The chambers increase gradually as they are added; the aperture is umbilical-extraumbilical with a distinct lip. This form differs from $N$. dutertrei dutertrei in that the aperture is umbilical-extraumbilical and the test is smaller. It differs from $N$. dutertrei blowi in having a higher spiral side, more lobulate equatorial periphery, and smaller size. This form is one of the most abundant of the upper Pliocene to Holocene sequence in the Guaymas Basin.

Neogloboquadrina pachyderma pachyderma (Ehrenberg) (Plate 4, Figs. 10, 11). Aristerospira pachyderma Ehrenberg, 1861, p. 276, 277, 303 (fide Ellis and Messina, 1940 et seq.). Ehrenberg, 1873, p. 386, pl. 1, fig. 4 (fide Ellis and Messina, 1940 et seq.). The typical form of the Guaymas Basin species has 4 chambers in the final whorl, a narrow umbilical aperture, and a small, quadrate, tightly coiled test, which is not lobulate. Encrustation is generally heavy, and the surface has a pitted, "sugar grain" texture. This form corresponds to $N$. pachyderma form 1 of Keller (1978a). It is a typical cold-water form (Bé, 1960) and is sinistrally coiled in the Arctic and Subarctic (Ericson, 1959; Keller, 1978a; Coulbourn et al., 1980). Nearly all Guaymas Basin specimens are dextrally coiled. This form is not abundant, but occurs, in general, in three Pleistocene intervals and nearly disappears in the Holocene sediment; however, it is possible that this form continued to survive, during the Holocene epoch in the northern Gulf.

Neogloboquadrina pachyderma (Ehrenberg) forma A (Plate 4, Figs. 12-14). This form has 4 globular chambers in the final whorl, with a quadrate outline and an umbilical-extraumbilical aperture with a faint rim-like lip. It differs from $N$. pachyderma pachyderma in that it is larger, more quadrate, and has a slightly lobulate equatorial outline. This form may correspond to $N$. pachyderma form 2 of Keller (1978a). All the specimens in the Basin are dextrally coiled. It is regarded as a temperate, transitional-water inhabitant and is one of the most predominant in the Basin Quaternary sequence; however, it seems to decrease in the upper Pleistocene and Holocene sequences.

Neogloboquadrina pachyderma (Ehrenberg) forma B (Plate 4, Figs. $15-19)$. This form has $4 \frac{1}{2}$ to 5 chambers in the final whorl, a lobulate equatorial periphery, and, frequently, an aberrant last chamber. It differs from $N$. pachyderma pachyderma in its larger, loosely coiled test and lobulate equatorial periphery. The test size is nearly the same as, or slightly smaller than, $N$. pachyderma forma A but differs in that it has more chambers in the final whorl, which shows a somewhat pentagonal appearance and a more Iobulate periphery. Some authors' Globigerina incompta Cifelli may be included in this form. Nearly all specimens are dextrally coiled. It is one of the predominant forms in the Quaternary sequence of the Guaymas Basin.

Orbulina suturalis Brönnimann. Orbulina suturalis Brönnimann, 1951, p. 135 , text fig. 2 , figs. $1,2,5-8$, text fig. 3 , figs. $3-8,11,13-16$, $18,20-22$, text fig. 4 , figs. $2-4,7-12,15,16,19-22$. Some specimens from a few Hole 478 and 479 samples are identical to this species.

Orbulina universa d'Orbigny (Plate 2, Fig. 16). Orbulina universa d'Orbigny, 1839 , p. 2, pl. 1, fig. 1. This species is rare to common and scattered in the Quaternary sequence.

Pulleniatina obliquiloculata (Parker and Jones) (Plate 2, Figs. 14, 15). Pullenia sphaeroides (d'Orbigny) var. obliquiloculata Parker and Jones, 1865 , p. 365 , pl. 19, figs. 4a, b. Banner and Blow, 1960, p. 
Holes 477 and $477 \mathrm{~A}$

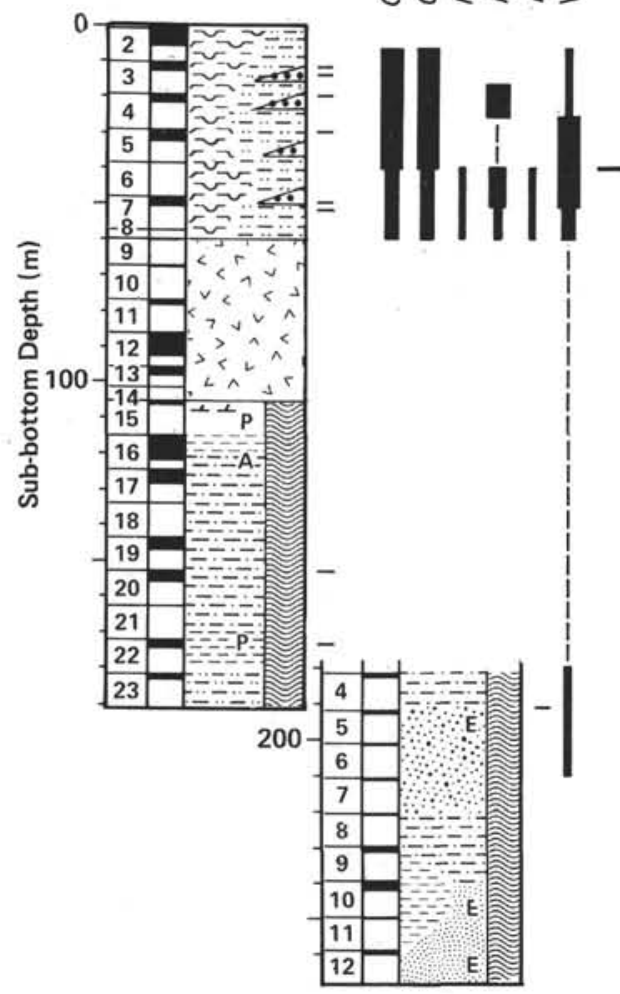

Hole 478

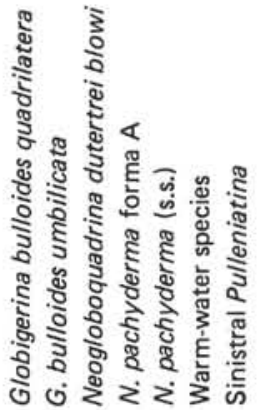

Holes 481 and $481 \mathrm{~A}$

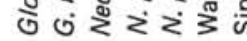

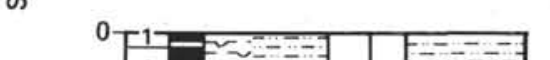

Figure 8. Correlation of the Guaymas Basin sites and the stratigraphic occurrence of some selected taxa. (Horizon $\mathrm{A}=$ last occurrence of Neogloboquadrina dutertrei blowi Rogl and Bolli; Horizon B = first abundant occurrence of Globigerina bulloides umbilicata Orr and Zaitzeff; Horizon $\mathrm{C}=$ first abundant occurrence of Globigerina bulloides quadrilatera Galloway and Wissler; Interval D-D' $=$ abundant occurrence of Neogloboquadrina pachyderma forma A.) 


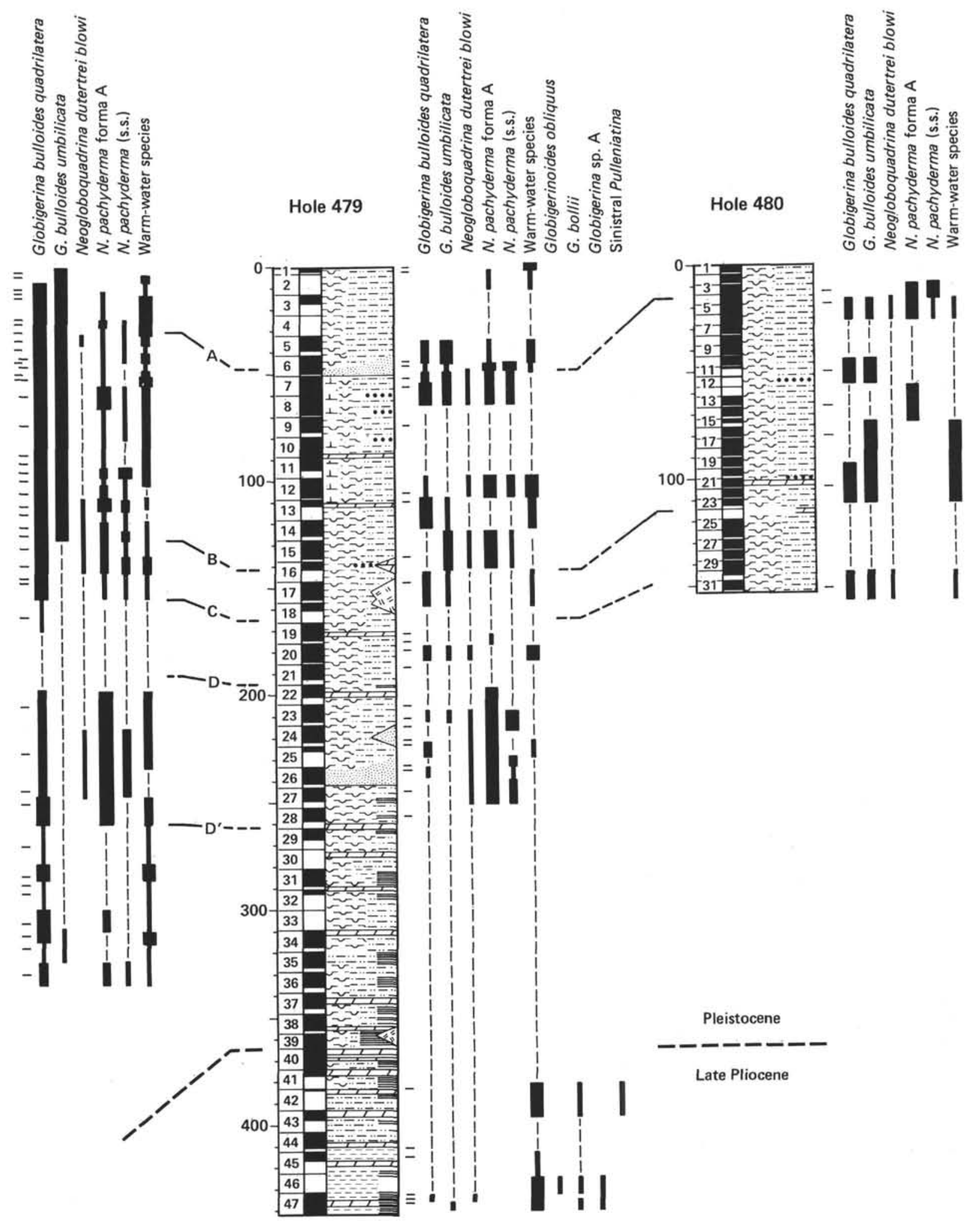

Figure 8. (Continued). 


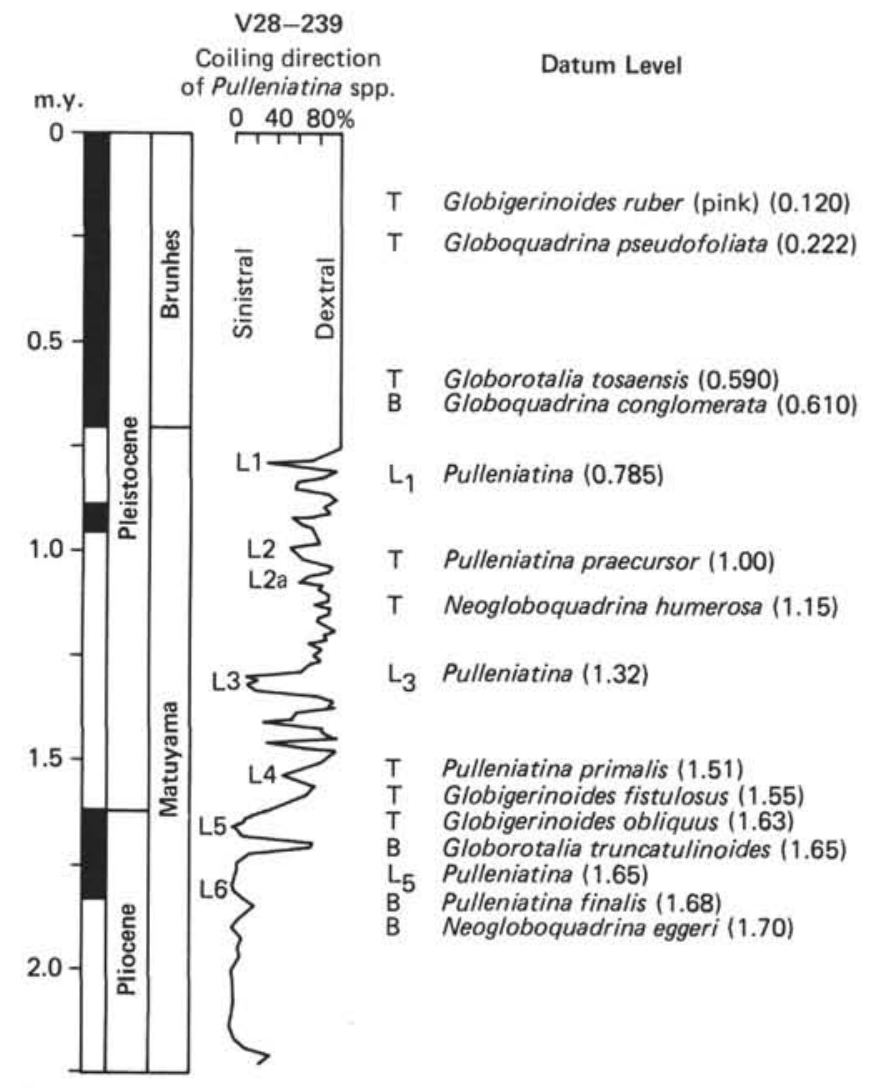

Figure 9. Coiling direction changes of Pulleniatina and planktonic foraminiferal datum levels dated by paleomagnetic time scale in the equatorial Pacific (simplified from Thompson and Sciarrillo, 1978).

25 , pl. 7, figs. 4a-c (lectotype). All the specimens belong to typical $P$. obliquiloculata species. The occurrence of this species ranges from rare to few and is sporadic in the upper Pliocene to Holocene sequence. Nearly all specimens are dextrally coiled except for those in Section 479-42,CC, where all 4 specimens are sinistrally coiled, and Samples 478-31-2, 84-86 cm and 478-35-4, 18-20 cm, where each specimen is sinistrally coiled among 2 and 1 specimens of the species, respectively.

Turborotalita anfracta (Parker) (Plate 5, Figs. 14-15B). Globorotalia anfracta Parker, 1967, p. 175, pl. 28, figs. 3-8. Turborotalita anfracta (Parker), Rogl and Bolli, 1973, p. 571, pl. 8, figs. 1-7, pl. 16, fig. 9. Some specimens from a few samples at Sites 478 and 481 are identical to this species.

Turboratalita guaymasensis n. sp. (See Description of New Species, this chapter.)

Turborotalita iota (Parker) (Plate 5, Figs. 17-18B). Globigerinita iota Parker, 1962 , p. 250 , pl. 10, figs. 26-30. This species has a small, low trochospiral test and $4 \frac{1}{2}$ to 5 chambers in the final whorl. The umbilicus is covered by a bulla, which extends somewhat to the intercameral sutures. In this chapter, the specimens without bulla were distinguished from the typical form.

Turborotalita iota (Parker) vars. (Plate 5, Figs. 19A-20). Specimens similar to $G$. iota-but without bulla-were tentatively distinguished from the typical form. There are some morphologic variations, and the test size is often larger than in the typical form.

Turborotalita $\mathrm{cf}$. T. parkerae (Bronnimann and Resig) (Plate 5, Figs. 16A-C) Cf. Globorotalia (Turboratalia) parkerae Bronnimann and Resig, 1971, p. 1280, 1281, pl. 43, figs. 7,10 , pl. 47 , figs. 4 , 6 , pl. 48 , figs. 2,3 . The very small test having the elongate final chamber and a bulbous appearance resembles $T$. parkerae but differs from it in having less radial elongation of the final chamber and slightly curved intercameral sutures on the umbilical side.

\section{DESCRIPTION OF NEW SPECIES}

Order FORAMINIFERIDA Eichwald, 1830

Family GLOBOROTALIIDAE Cushman, 1927 Genus TURBORATALITA Blow and Banner, 1962

Turborotalita guaymasensis Matoba and Oda, n. sp. (Plate 5, Figs. 1A-13B)

Description of Holotype. Test small, coiled in a trochospire with 15 globular chambers in all, arranged in 3 whorls, 5 in the final whorl; equatorial periphery fairly lobulate, somewhat pentagonal in outline; axial periphery broadly rounded. Chambers globular, inflated, gently embracing one another, increasing progressively in size as added, except for the ultimate chamber, which is slightly smaller than the penultimate chamber. Earlier 2 whorls very low trochospiral, forming the nearly flat spiral side; but the final whorl becomes a high trochospiral with a tendency to streptospiral. The last chamber tilts toward the umbilicus. Sutures on both spiral and umbilical sides radial to slightly curved and depressed. Umbilicus deep, open but small. Aperture interiomarginal; umbilical-extraumbilical in position, broad, low arch, bordered by a distinct, narrow lip. Wall is thin, finely perforate, and very finely pitted, without spines or spine bases. The wall of the ultimate chamber somewhat thinner and less densely perforate than the earlier chambers. Coiling sinistral.

Holotype. Plate 5, Figures 1A-D; deposited at the Institute of Geology and Paleontology, Tohoku University, Sendai, Japan (IGPS Coll. Cat. 96730).

Dimensions (holotype). Largest diameter $=0.22 \mathrm{~mm}$; height of spire $=0.184 \mathrm{~mm}$.

Type Locality. Deep Sea Drilling Project Leg 64, Site 478, Core 22 , Section 1, 28-31 cm; Guaymas Basin, Gulf of California, $27^{\circ} 05.81^{\prime} \mathrm{N}$; $111^{\circ} 30.45^{\prime} \mathrm{W}$. Water depth $=1889$ meters.

Type Level. Pleistocene.

Paratypes. Plate 5, Figures 2A-13B (IGPS Coll. Cat. 9673196742). Unfigured paratypes (162 specimens) are deposited at the Institute of Mining Geology, Mining College, Akita University, Akita, Japan.

Dimensions (paratypes). Diameter $=0.162-0.242 \mathrm{~mm}$; height of spire $=0.121-0.202 \mathrm{~mm}$. Average diameter $=0.195 \mathrm{~mm}$; average height of spire $=0.156 \mathrm{~mm}$.

Number of Chambers (paratypes). 10-16; average $=13.6$ chambers arranged in $2^{+}$to 3 whorls; 12 and 15 chamber forms are common. Number of chambers in ultimate whorl $=4-5$, rarely $51 / 2-6$; $5-5 \frac{1}{2}$ in penultimate whorl.

Remarks. Characteristically becoming high trochospiral with a tendency to streptospiral coiling in the later stage of growth. Because of this coiling mode, the last chamber is usually tilted toward the umbilicus. The last chamber varies greatly in morphology, position, and wall character. In some specimens, the last chamber is normal in size and larger than the penultimate chamber, but often in others it is smaller than the penultimate chamber and is globose, elongate, reduced, or aberrant in shape. The wall of the last chamber is often thinner and less densely perforate than the wall of earlier chambers. In some specimens, the last chamber is completely umbilical and invisible from the spiral side (Plate 5, Figs. 8, 11); in an extreme case, the last chamber resembles a bulla (Plate 5, Figs. 6, 8) or shows an elongation onto the umbilicus (Plate 5, Fig. 9), as does Globigerina quinqueloba. A few specimens have an elongate last chamber toward the umbilicus as seen in $G$. bermudezi. The shape of the aperture varies because of the variation of the last chamber, but it is always bordered by a distinct lip. The morphology of the umbilicus varies from open to nearly closed, according to the shape and position of the last chamber and to the coiling mode, which ranges from rather loosely coiled to tightly coiled. A $4 \frac{1}{2}-5$ chambered, moderately coiled form such as the holotype seems to be typical, though the $4-41 / 2$ chambered, tightly coiled form with the umbilicus almost closed (Plate 5, Figs. 4-5B) and the 5-chambered form with a bulla-like or reduced last chamber on the umbilical side (Plate 5, Figs. 6-8) are also common. The 51/2-6 chambered and rather loosely coiled form (Plate 5, Figs. 13A, B) is very rare. Sometimes, overlapping of lips of the previous apertures can be seen through the umbilicus when it is open.

Comparison. Turborotalita guaymasensis differs from Globigerinita iota Parker in the higher spired, thicker test, rougher wall, and 


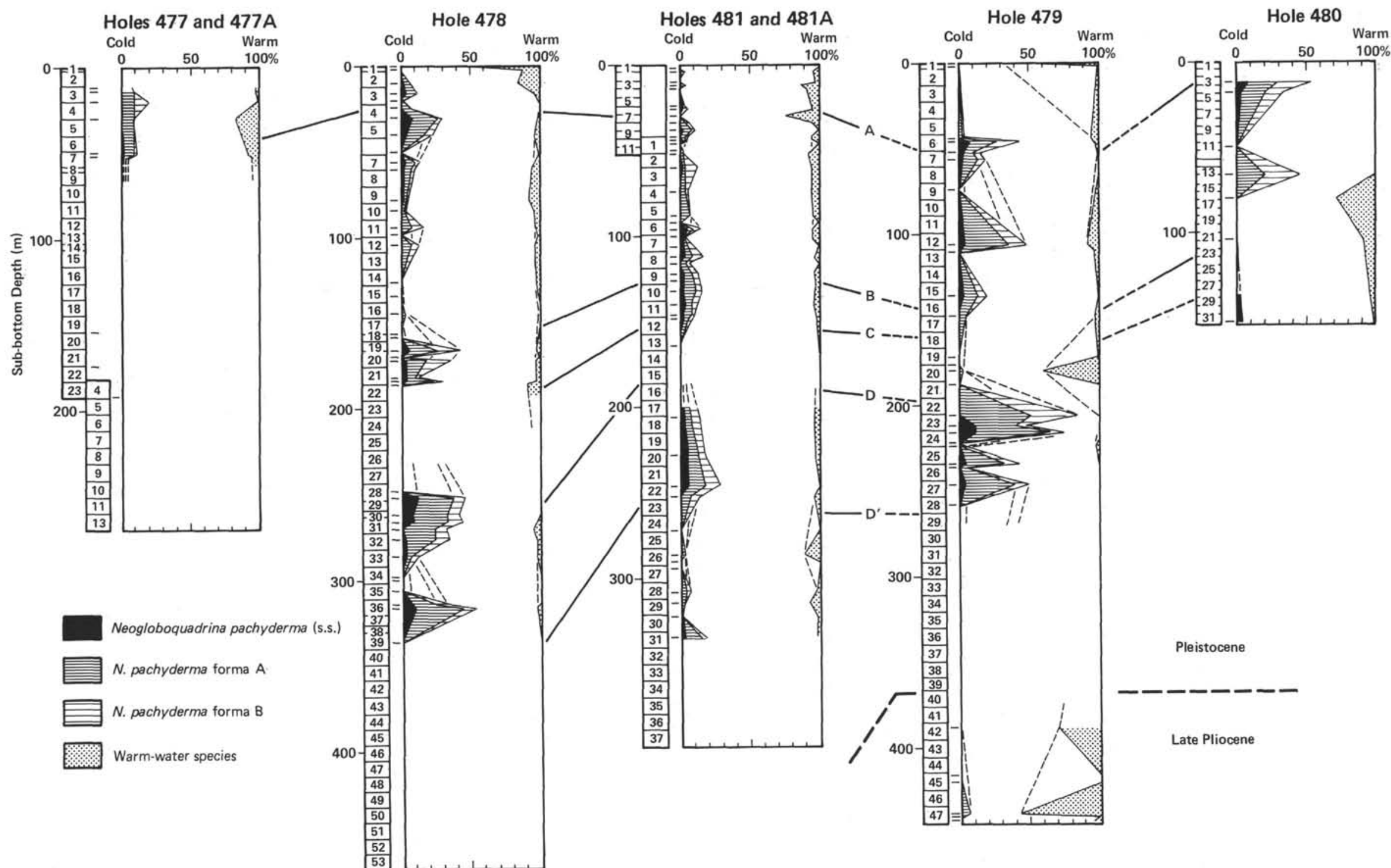

Figure 10. Vertical frequency distribution of warm and cold species, Sites 477 through 481 . (Dashed line in the graphs indicates samples containing less than 30 specimens of planktonic foraminifers [disregarded]. See Fig. 8 for Horizons A-D'. 
absence of true bulla. The senior author examined many paratypes of G. iota at the Scripps Institution of Oceanography (courtesy of Ms. F. L. Parker). Turborotalita guaymasensis resembles Globigerina sp. A of Poore (1979, p. 469, pl. 19, figs. 5-12), reported from the North Atlantic DSDP cores, which range from late Miocene to Quaternary. The form is thin-walled and nonspinose(?) having 4-6 chambers in the ultimate whorl and an open and deep umbilicus. Such a form is very rare and occurs at the end of the variation of our material from the Gulf. Turborotalita guaymasensis differs from Globigerina tarchanensis Subbotina and Khutsieva from the Miocene sequence of the Crimea-Caucasus, Soviet Union (1950) in having a higher trochospiral-to-streptospiral test. Turborotalita guaymasensis also differs from Globigerina megastoma Earland in its flat spiral side in earlier whorls, having chambers not as rapidly increasing in size as gradually added and has a much smaller test. It differs from G. megastoma carinacoensis Rögl and Bolli because of a lip, the absence of spines, and the much smaller size.

Occurrence. This species occurs only sporadically at all sites from Site 477 through 481 , but is abundant in Cores 478-21, 478-22, 479-7, and 479-13. Pleistocene.

\section{ACKNOWLEDGMENTS}

We wish to thank the Deep Sea Drilling Project and D. G. Moore and J. R. Curray, co-chief scientists on Leg 64, for giving the senior author the opportunity to participate in Leg 64 . We especially thank J. C. Ingle, Jr. of Stanford University for various suggestions on the Gulf of California, foraminiferal paleoecology, and for reading the manuscript. Thanks are also due to F. L. Parker of the Scripps Institution of Oceanography for allowing the senior author to examine her planktonic foraminiferal specimens and for reviewing the MS. We acknowledge Y. Takayanagi of Tohoku University, T. Saito of Yamagata University, and G. Keller of Stanford University for reading the manuscript and K. Shibata and A. Yamaguchi of Akita University for drafting the illustrations and assisting in the laboratory.

\section{REFERENCES}

Bandy, O. L., 1961. Distribution of Foraminifera, Radiolaria and diatoms in the sediments of the Gulf of California. Micropaleontology, 7:1-26.

Bandy, O. L., and Ingle, J. C., Jr., 1970. Neogene planktonic events and radiometric scale, California. In Bandy, O. L. (Ed.), Radiometric Dating and Paleontologic Zonation: Spec. Pap. Geol. Soc. Am., 124:131-172.

Banner, F. T., and Blow, W. H., 1960. Some primary types of species belonging to the superfamily Globigerinaceae. Contrib. Cushman Found. Foraminiferal Res., 11:1-41.

Bé, A. W. H., 1960. Some observations on arctic planktonic Foraminifera. Contrib. Cushman Found. Foraminiferal Res., 11:64-68. 1977. An ecological, zoogeographic and taxonomic review of Recent planktonic Foraminifera. In Ramsay, A. T. S. (Ed.), Oceanic Micropalaeontology (Vol. 1): London (Academic), 1-88.

Bé, A. W. H., and Tolderlund, D. S., 1971. Distribution and ecology of living planktonic Foraminifera in surface waters of the Atlantic and Indian oceans. In Funnell, B. M., and Riedel, W. R. (Eds.), The Micropaleontology of Oceans: Cambridge (Cambridge University Press), pp. 105-149.

Blow, W. H., 1959. Age, correlation, and biostratigraphy of the upper Tocuyo (San Lorenzo) and Pozón formations, eastern Falcón, Venezuela. Bull. Am. Paleontol., 39:67-251.

1969. Late middle Eocene to Recent planktonic foraminiferal biostratigraphy. In Brönnimann, P., and Renz, H. H. (Eds.), Proceedings of the First International Conference on Planktonic Microfossils (Vol. 1): Leiden (E. J. Brill), 199-422.

Bolli, H. M., 1957. Planktonic Foraminifera from the Oligocene-Miocene Cipero and Lengua formations of Trinidad, B.W.I. U.S. Natl. Mus. Bull., 215:97-123.

Bradshaw, J. S., 1959. Ecology of living planktonic Foraminifera in the North and equatorial Pacific Ocean. Contr. Cushman Found. Foraminiferal Res., 10:25-64.

Brady, H. B., 1884. Report on the Foraminifera collected by H.M.S. Challenger during the year 1873-1876. Report on the Scientific Results of the Voyage of Challenger. Zoology, 9:1-814.

Brönnimann, P., 1951. The genus Orbulina in the Oligo-Miocene of Trinidad, B.W.I. Contr. Cushman Found. Foraminiferal Res., 2:132-138.
Brönnimann, P., and Resig, J., 1971. A Neogene globigerinacean biochronologic time-scale of the southwestern Pacific. In Winterer, E. L., Reidel, W. R., et al., Init. Repts. DSDP, 7, Pt. 2: Washington (U.S. Govt. Printing Office), 1235-1469.

Coulbourn, W. T., Parker, F. L., and Berger, W. H., 1980. Faunal and solution patterns of planktonic Foraminifera in surface sediments of the North Pacific. Mar. Micropaleontol., 5:329-399.

Curray, J. R., Moore, D. G., and Aguayo, J. E., et al., 1979. In the Gulf of California, Leg 64 seeks evidence on development of basins. Geotimes, 24:18-20.

Ellis, B. F., and Messina, A. R., 1940-. A Catalogue of Foraminifera (30 vols. and supplement vols.): New York (American Museum of Natural History).

Ericson, D. B., 1959. Coiling direction of Globigerina pachyderma as a climatic index. Science, 130:219-220.

Galloway, J. J., and Wissler, S. G., 1927. Pleistocene Foraminifera from the Lomita Quarry, Palos Verdes Hills, California. J. Paleontol., 1:35-87,

Hays, J. D., Saito, T., Opdyke, N. D., et al., 1969. Pliocene-Pleistocene sediments of the equatorial Pacific: Their paleomagnetic, biostratigraphic, and climatic record. Geol. Soc. Am. Bull., 80: $1481-1514$.

Ingle, J. C., Jr., 1973a. Neogene Foraminifera from the northeastern Pacific Ocean, Leg 18, Deep Sea Drilling Project. In Kulm, L. D., von Huene, R., et al., Init. Repts. DSDP, 18: Washington (U.S. Govt. Printing Office), 517-567.

1973b. Summary comments on Neogene biostratigraphy, physical stratigraphy, and paleo-oceanography in the marginal northeastern Pacific Ocean. In Kulm, L. D., von Huene, R., et al., Init. Repts. DSDP, 18: Washington (U.S. Govt. Printing Office), 949-960.

, 1973c. Neogene marine history of the Gulf of California; foraminiferal evidence. Geol. Soc. Am. Abstract with Programs, 5:62. (Abstract)

1974. Paleobathymetric history of Neogene marine sediments, northern Gulf of California. In Gastil, G., and Lillegraven, J. (Eds.), The Geology of Peninsular California, Guidebook, 49th Annual Meeting: Pacific Sections of the American Association of Petroleum Geologists and the Society of Economists and Paleontological Mineralogists, San Diego, 121-138.

,1977a. Summary of late Neogene planktonic foraminiferal biofacies, biostratigraphy, and paleoceanography of the marginal North Pacific Ocean. In Saito, T., and Ujiie, H. (Eds.), Proceedings of the First International Conference on Pacific Neogene Stratigraphy: Tokyo (Kaiyo Shuppan), pp. 177-182. (Abstract)

, 1977b. Late Neogene marine events and the PliocenePleistocene boundary in the marginal North Pacific. Proceedings II Symposium, Neogene-Quaternary Boundary, G. Geol., 41: 359-374.

Jenkins, D. G., and Orr, W. N., 1972. Planktonic foraminiferal biostratigraphy of the eastern equatorial Pacific-DSDP Leg 9. In Hays, J. D., et al., Init. Repts. DSDP, 9: Washington (U.S. Govt. Printing Office), 1059-1093.

Karig, D. E., and Jensky, W., 1972. The proto-Gulf of California. Earth Planet. Sci. Lett., 17:169-174.

Keller, G., 1978a. Morphologic variation of Neogloboquadrina pachyderma (Ehrenberg) in sediments of the marginal and central northeast Pacific Ocean and paleoclimatic interpretation. J. Foram. Res., 8:208-224.

, 1978b. Late Neogene planktonic foraminiferal biostratigraphy and paleoceanography of the northeastern Pacific: Evidence from DSDP Sites 173 and 310 at the North Pacific Front. $J$. Foram. Res., 8:332-349.

1979a. Late Neogene paleoceanography of the North $\mathrm{Pa}$ cific DSDP Sites 173, 310, and 296. Mar. Micropaleontol., 4: 159-172.

1979b. Early Pliocene to Pleistocene planktonic foraminiferal datum levels in the North Pacific: DSDP Sites 173, 310, 296. Mar. Micropaleontol., 4:281-294.

Larson, R. L., Menard, H. W., and Smith, S. M., 1968. Gulf of California: A result of ocean-floor spreading and transform faulting. Science, 161:781-784.

Matoba, Y., 1967. Younger Cenozoic foraminiferal assemblages from the Choshi district, Chiba Prefecture. Sci. Rep. Tohoku Univ., Ser. 2, 38:221-263. 
Moore, D. G., 1973. Plate edge deformation and crustal growth, Gulf of California structural province. Geol. Soc. Am. Bull., 84:18831906.

Moore, D. G., and Buffington, E. C., 1968. Transform faulting and growth of the Gulf of California since the Late Pliocene. Science, 161:1238-1241.

Natland, M. L., 1938. New species of Foraminifera from the west coast of North America and from the later Tertiary of the Los Angeles Basin. Bull. Scripps Inst. Oceanog., 4:137-163.

, 1950. Report on the Pleistocene and Pliocene Foraminifera. 1940 E. W. Scripps Cruise to the Gulf of California, Pt. 4: Geol. Soc. Am. Mem., 43:1-55.

Oda, M., 1977. Planktonic foraminiferal biostratigraphy of late Cenozoic sedimentary sequence, central Honshu, Japan. Sci. Rep. Tohoku Univ., Ser. 2, 48:1-72.

Olsson, R. K., 1971. Pliocene-Pleistocene planktonic foraminiferal biostratigraphy of the northeastern Pacific. In Fariacci, A. (Ed.), Proceedings of the Second International Conference on Planktonic Microfossils (Vol. 1): Rome (Edizione Tecnoscienza), 921928.

d'Orbigny, A., 1839. Foraminifères. In de la Sagra, R. (Ed.), Historie physique, politique et naturelle de l'île de Cuba: Paris (A. Bertrand).

1846. Foraminifères fossiles du Bassin Tertiaire de Vienne (Autriche): Paris (Gide et Comp ${ }^{e}$ ).

Orr, W. N., and Zaitzeff, J. B., 1971. A new planktonic foraminiferal species from the California Pliocene. J. Foraminiferal Res., 1:1719.

Parker, F. L., 1958. Eastern Mediterranean Foraminifera. Rep. Swed. Deep-Sea Exped., 8:219-283.

, 1962. Planktonic foraminiferal species in Pacific sediments. Micropaleontology, 8:219-254.

1967. Late Tertiary biostratigraphy (planktonic Foraminifera) of tropical Indo-Pacific deep-sea cores. Bull. Am. Paleontol., 52:115-208.

, 1973. Living planktonic Foraminifera from the Gulf of California. J. Foraminiferal Res., 3:70-77.

Parker, F. L., and Berger, W. H., 1971. Faunal and solution patterns of planktonic Foraminifera in surface sediments of the South $\mathrm{Pa}$ cific. Deep-Sea Res., 18:73-107.

Parker, W. K., and Jones, T. R., 1865. On some Foraminifera from the North Atlantic and Arctic oceans, including Davis Straits and Baffin's Bay. Philos. Trans. R. Soc. London, 155:325-441.
Poore, R. Z., 1979. Oligocene through Quaternary planktonic foraminiferal biostratigraphy of the North Atlantic: DSDP Leg 49. In Luyendyk, B. P., Cann, J. R., et al., Init. Repts. DSDP, 49: Washington (U.S. Govt. Printing Office), 447-517.

Roden, G. I., and Groves, G. W., 1959. Recent oceanographic investigations in the Gulf of California. J. Mar. Res., 8:10-35.

Rögl, F., and Bolli, H. M., 1973. Holocene to Pleistocene planktonic Foraminifera of Leg 15, Site 147 (Cariaco Basin [Trench], Caribbean Sea) and their climatic interpretation. In Edgar, N. T., Saunders, J. B., et al., Init. Repts. DSDP, 15: Washington (U.S. Govt. Printing Office), 553-616.

Saito, T., 1976. Geologic significance of coiling direction in the planktonic Foraminifera Pulleniatina. Geology, 4:305-309.

1977. Late Cenozoic planktonic foraminiferal datum levels: The present state of knowledge toward accomplishing panPacific stratigraphic correlation. In Saito, T., and Ujiie, H. (Eds.), Proceedings of the First International Congress on Pacific Neogene Stratigraphy: Tokyo (Kaiyo Shuppan), pp. 61-80.

Saito, T., Burckle, L. H., and Hays, J. D., 1975. Late Miocene to Pleistocene biostratigraphy of equatorial Pacific sediments. In Saito, T., and Burckle, L. H. (Eds.), Late Neogene Epoch Boundaries: Micropaleontology Special Publication, 1:226-244.

Seiglie, G. A., 1963. Una nueva especie del género Globigerina del Reciente de Venezuela. Bol. Inst. Oceanog. Univ. Oriente, 2:89-93.

Smith, P. B., 1970. New evidence for a Pliocene marine embayment along the lower Colorado River area, California and Arizona. Geol. Soc. Am. Bull., 81:1411-1420.

Srinivasan, M. S., and Kennett, J. P., 1976. Evolution and phenotypic variation in the Late Cenozoic Neogloboquadrina dutertrei plexus. In Takayanagi, Y., and Saito, T. (Eds.), Progress in Micropaleontology: Selected Papers in Honor of Prof. Kiyoshi Asano: New York (Micropaleontology Press), pp. 329-355.

Thompson, P. R., 1976. Planktonic foraminiferal dissolution and the progress towards a Pleistocene equatorial Pacific transfer function. J. Foraminiferal Res., 6:208-227.

1980. Foraminifers from Deep Sea Drilling Project Sites 434, 435, and 436, Japan Trench. In Scientific Party, Init. Repts. DSDP, 56, 57, Pt. 2: Washington (U.S. Govt. Printing Office), 775-807.

Thompson, P. R., and Sciarrillo, J. R., 1978. Planktonic foraminiferal biostratigraphy in the equatorial Pacific. Nature, 275:29-33. 


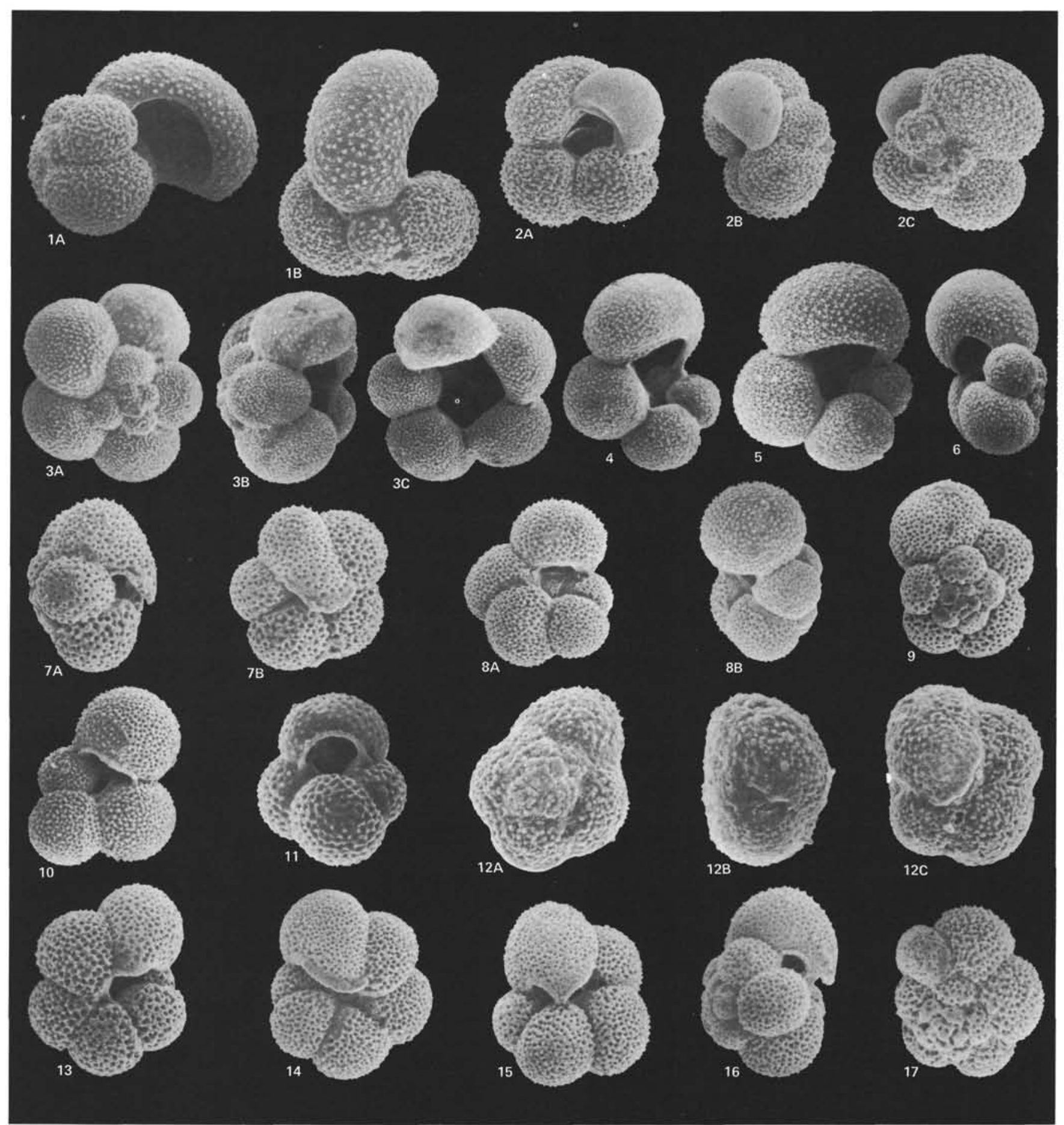

Plate 1. Late Pliocene to Holocene planktonic foraminifers. 1A, B. Globigerina bermudezi Seiglie. $\times 100$. (1A) side view, slightly oblique. (1B) oblique spiral view (AKMG 11001). Section 481A-3,CC. 2A-C. Globigerina bulloides quadrilatera Galloway and Wissler. $\times 100$. (2A) umbilical view. (2B) side view. (2C) spiral view (AKMG 11002). Section 478-10,CC. 3A-4. Globigerina bulloides umbilicata Orr and Zaitzeff. $\times 76$. (3A) spiral view. (3B) side view. (3C) umbilical view (AKMG 11003a). (4) umbilical view (AKMG 11003b). Sample 481A-2-1, 75-77 cm. 5, 6. Globigerina bulloides bulloides d'Orbigny, $\times 88$. (5) umbilical view (AKMG 11004a). (6) side view (AKMG 11004b). Section 478-2,CC. 7A, B. Globigerina quinqueloba Natland. $\times 125$. (7A) side view. (7B) umbilical view (AKMG 11005). Section 480-21,CC. 8A-9. Globigerina cf. G. quinqueloba Natland. $\times 100$. (8A) umbilical view. (8B) side view (AKMG 11006a). (9) spiral view (AKMG 11006b). Section 480-21,CC. 10. Globigerina falconensis Blow. $\times 100$, umbilical view (AKMG 11007). Section 480-16,CC. 11. Globigerina rubescens Hofker. $\times 130$, umbilical view (AKMG 11008). Section 481-11,CC. 12A-C. Globigerina sp. A. $\times 125$. (12A) spiral view. (12B) side view. (12C) umbilical view (AKMG 11009). Sample 479-47-6, 35-37 cm. 13-17. Globigerina sp. B. $\times 125$. (13-15) (AKMG 11010a-c), umbilical views. (16) oblique side view (AKMG 11010d). (17) spiral view (AKMG 11010e). Section 480-21,CC. 


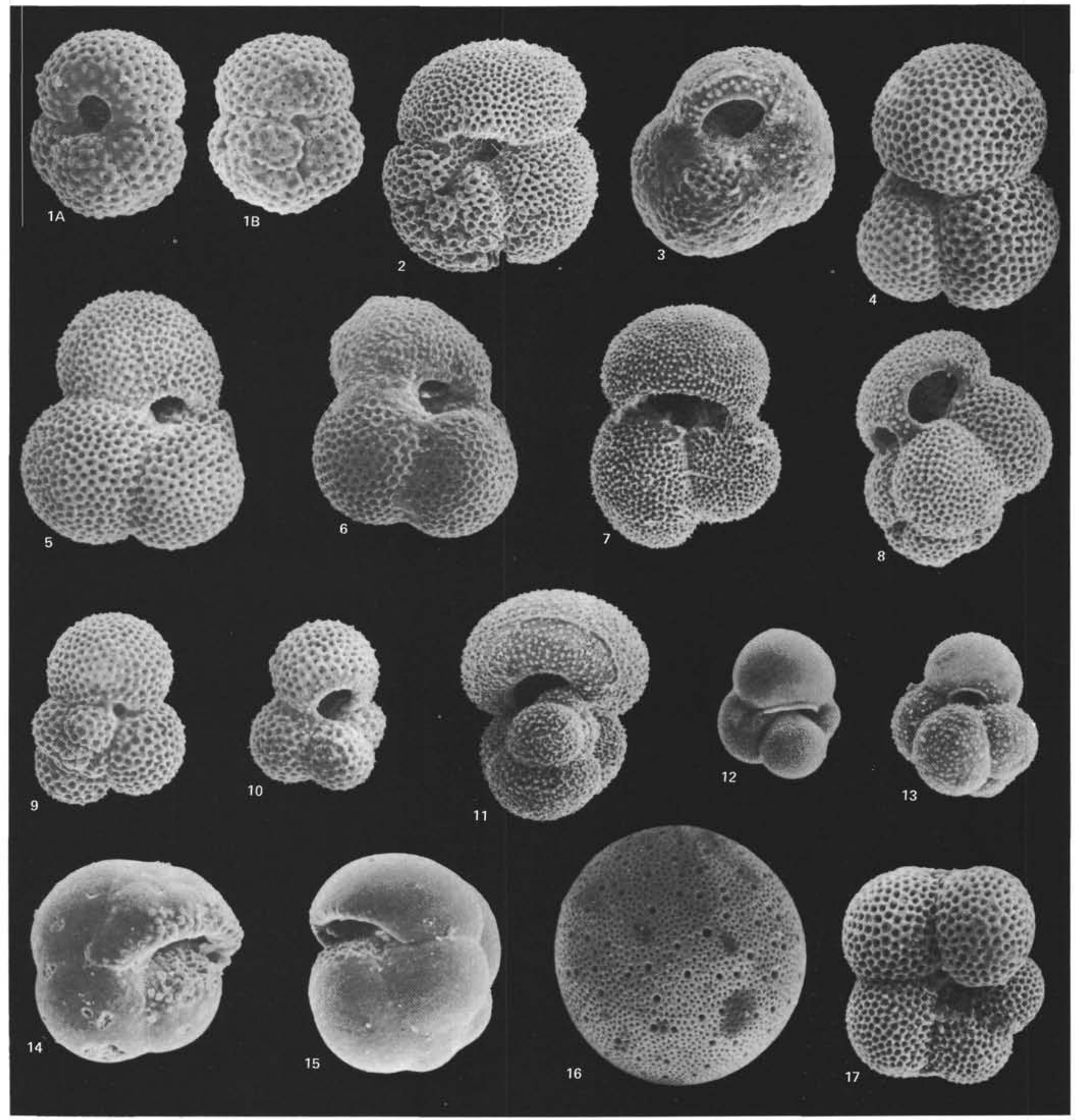

Plate 2. Late Pliocene to Holocene planktonic foraminifers. 1A, B. Globigerinoides bollii Blow, $\times 130$. (1A) umbilical view, slightly oblique. (1B) oblique spiral view (AKMG 11011). Section 479-42,CC. 2. Globigerinoides conglobatus (Brady). $\times 70$, oblique spiral view (AKMG 11012). Section 481A-3,CC. 3. Globigerinoides obliquus Bolli. $\times 100$, umbilical view (AKMG 11013). Sample 479-47-5, 47-49 cm. 4. Globigerinoides quadrilobatus quadrilobatus (d'Orbigny). $\times 88$, umbilical view (AKMG 11014). Sample 479-20-2, 29-31 cm. 5, 6. Globigerinoides quadrilobatus sacculifer (Brady). $\times 88$, umbilical views (AKMG 11015a, b). (5) Sample 479-20-2, 29-31 cm. (6) Sample 479-47-6, 35-37 cm. 7. Globigerinoides ruber ruber (d'Orbigny). ×75, umbilical view (AKMG 11016). Section 481-3,CC. 8. Globigerinoides ruber elongatus (d'Orbigny). $\times 88$, oblique side view (AKMG 11017). Section 481-3,CC. 9, 10. Globigerinoides tenellus Parker. $\times 100$. (9) spiral view (AKMG 11018a). (10) oblique umbilical view (AKMG 11018b). (9) Sample 478-7-6, 84-86 cm. (10) Sample 481A-1-1, 36-38 cm. 11. Globigerinella aequilateralis (Brady). $\times 75$, side view (AKMG 11019). Section 478-10,CC. 12. Globigerinita glutinata (Egger). $\times 125$, umbilical view (AKMG 11020). Section 478-2,CC. 13. Globigerinita uvula (Ehrenberg). $\times 125$, umbilical view (AKMG 11021). Sample 479-6-2, 71-74 cm. 14, 15. Pulleniatina obliquiloculata (Parker and Jones). $\times 88$. (14) umbilical view (AKMG 11022a). (15) side view (AKMG 11022b). Section 479-42,CC. 16. Orbulina universa d'Orbigny. $\times 88$. (AKMG 11023). Sample 478-7-3, 80-82 cm. 17. Globorotaloides hexagonus (Natland). $\times 125$, umbilical view (AKMG 11024). Sample 478-22-1, 28-31 cm. 


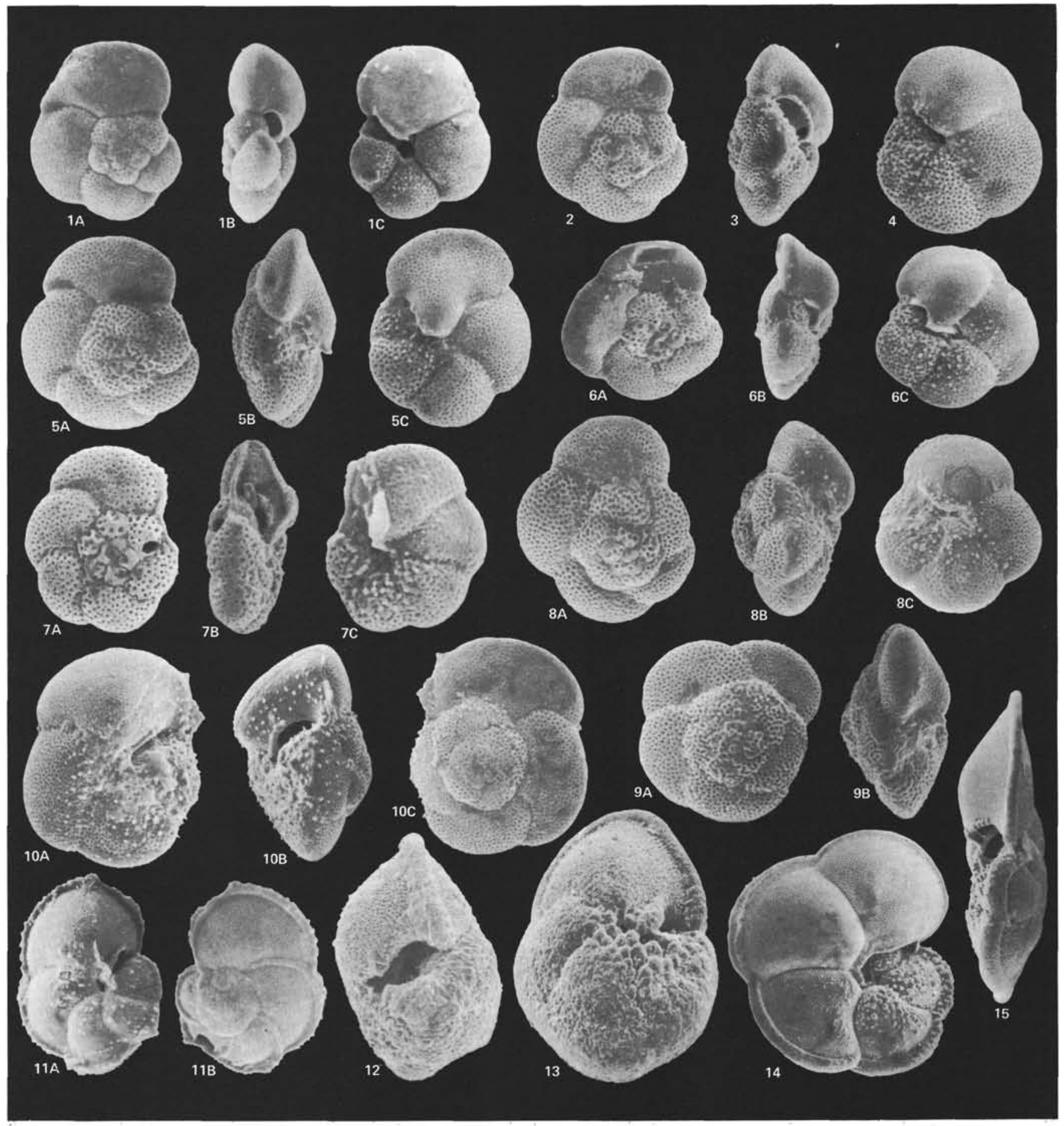

Plate 3. Late Pliocene to Holocene planktonic foraminifers. 1A-C. Globorotalia cf. G. bermudezi Rögl and Bolli. $\times 125$. (1A) spiral view. (1B) side view. (1C) umbilical view (AKMG 11025). Sample 481A-2-1, 75-77 cm. 2-4. Globorotalia scitula (Brady). $\times 88$. (2) spiral view (AKMG 11026a). (3) side view (AKMG 11026b). (4) umbilical view (AKMG 11026c). Section 478-3,CC. 5A-6C. Globorotalia cf. G. scitula (Brady). (5A, 6A) spiral views. (5B, 6B) side views. $(5 \mathrm{C}, 6 \mathrm{C})$ umbilical views. $(5 \mathrm{~A}-\mathrm{C}) \times 88$. (AKMG 11027a). Sample 481A-10-3, 20-22 cm. (6A-C) $\times$ 113. (AKMG 11027b). Sample 481A-2-1, 75-77 cm. 7A-C. Globorotalia sp. A. $\times 125$. (7A) spiral view. (7B) side view. (7C) umbilical view (AKMG 11028). Section 481A-29,CC. 8A-9B. Globorotalia sp. B. $\times 90$. (8A, 9A) spiral views. (8B, 9B) side views. (8C) umbilical view. (8A-C) (AKMG 11029a). (9A, B) (AKMG 11029b). Sample 481A-10-3, 22-24 cm. 10A-C. Globorotalia crassaformis (Galloway and Wissler). $\times 88$. (10A) umbilical view. (10B) side view. (10C) spiral view (AKMG 11030). Sample 478-22-1, 28-31 cm. 11A, B. Globorotalia fimbriata (Brady). $\times 100$. (11A) umbilical view. (11B) spiral view (AKMG 11031). Sample 481A-26-3, 72-74 cm. 12, 13. Globorotalia tumida (Brady). $\times 75$. (12) side view (AKMG 11032a). (13) umbilical view (AKMG 11032b). Section 479-42,CC. 14,15. Globorotalia cultrata (d'Orbigny). $\times 60$. (14) umbilical view (AKMG 11033a). (15) side view (AKMG 11033b). Sample 481-10-2, 69-71 cm. 


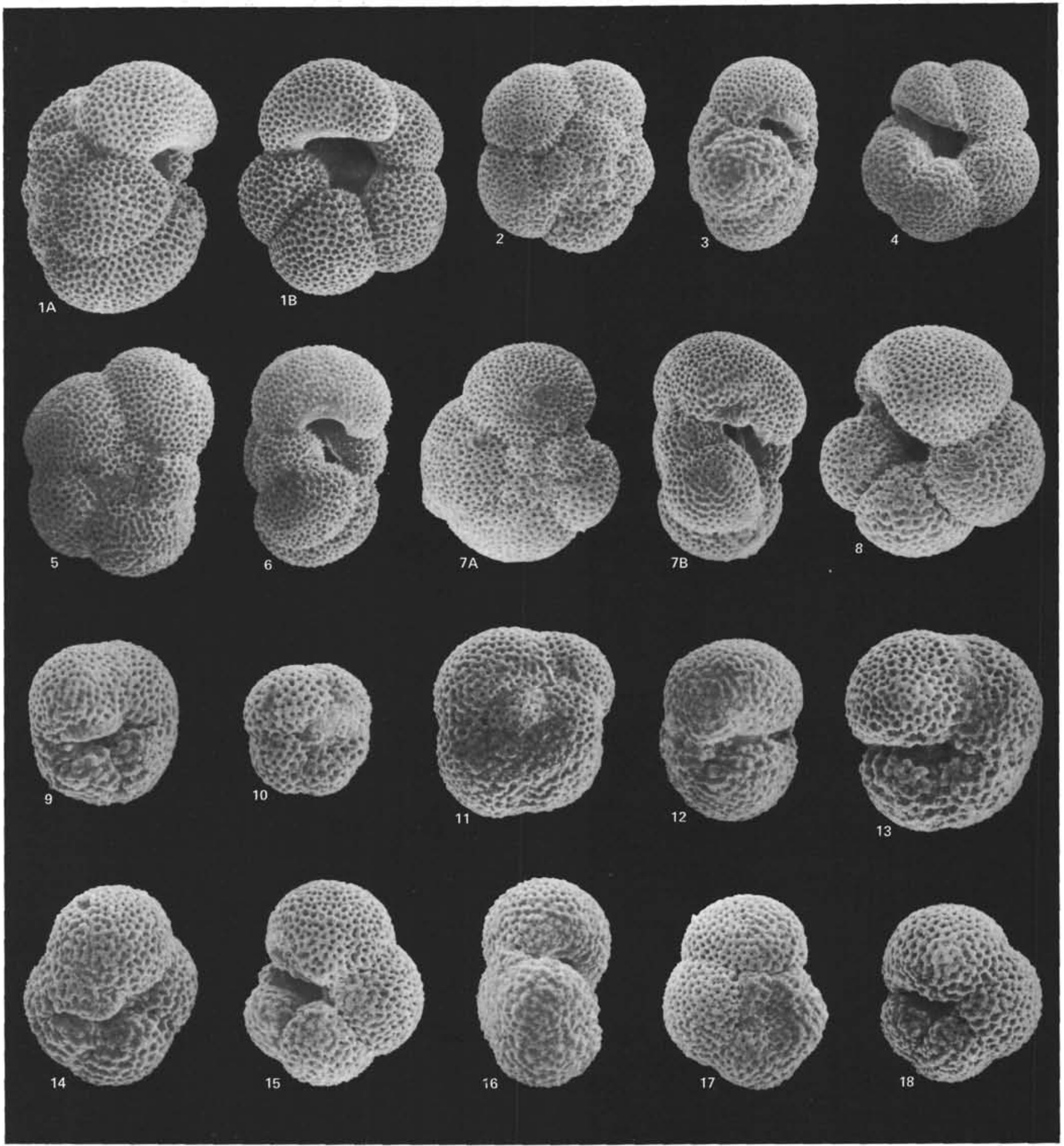

Plate 4. Late Pliocene to Holocene planktonic foraminifers. 1A, B. Neogloboquadrina dutertrei dutertrei (d'Orbigny). $\times 75$. (1A) side view. (1B) umbilical view (AKMG 11034). Sample 478-12-3, 139-141 cm. 2-4. Neogloboquadrina dutertrei (d'Orbigny) forma A. $\times 88$. (2) spiral view (AKMG 11035a). (3) side view (AKMG 11035b). (4) umbilical view (AKMG 11035c). Sample 479-7-2, 73-75 cm. 5-8. Neogloboquadrina dutertrei blowi Rögl and Bolli. $\times$ 75. (5, 7A) spiral views (AKMG 11036a,c). (6[AKMG 11036b], 7B) side views. (8) umbilical view (AKMG 11036d). (5) Sample 481A-8-2, 26-28 cm. (6) Sample 479-20-2, 29-31 cm. (7) Section 478-10,CC. (8) Section 478-28,CC. 9, 10. Neogloboquadrina pachyderma pachyderma (Ehrenberg). $\times 125$. (9) umbilical view (AKMG 11037a). (10) side view (AKMG 11037b). Section 478-4,CC. 11-13. Neogloboquadrina pachyderma (Ehrenberg) forma A. $\times 88$. (11) spiral view (AKMG 11038a). (12) side view (AKMG 11038b). (13) umbilical view (AKMG 11038c). Section 478-4,CC. 14-18. Neogloboquadrina pachyderma (Ehrenberg) forma B. $\times 125 .(14,15,18)$ umbilical views (AKMG 11039a,b,e). (16) side view (AKMG 11039c). (17) spiral view (AKMG 11039d). (14-17) Sample 479-7-2, 73-75 cm. (18) Section $478-4, \mathrm{CC}$. 


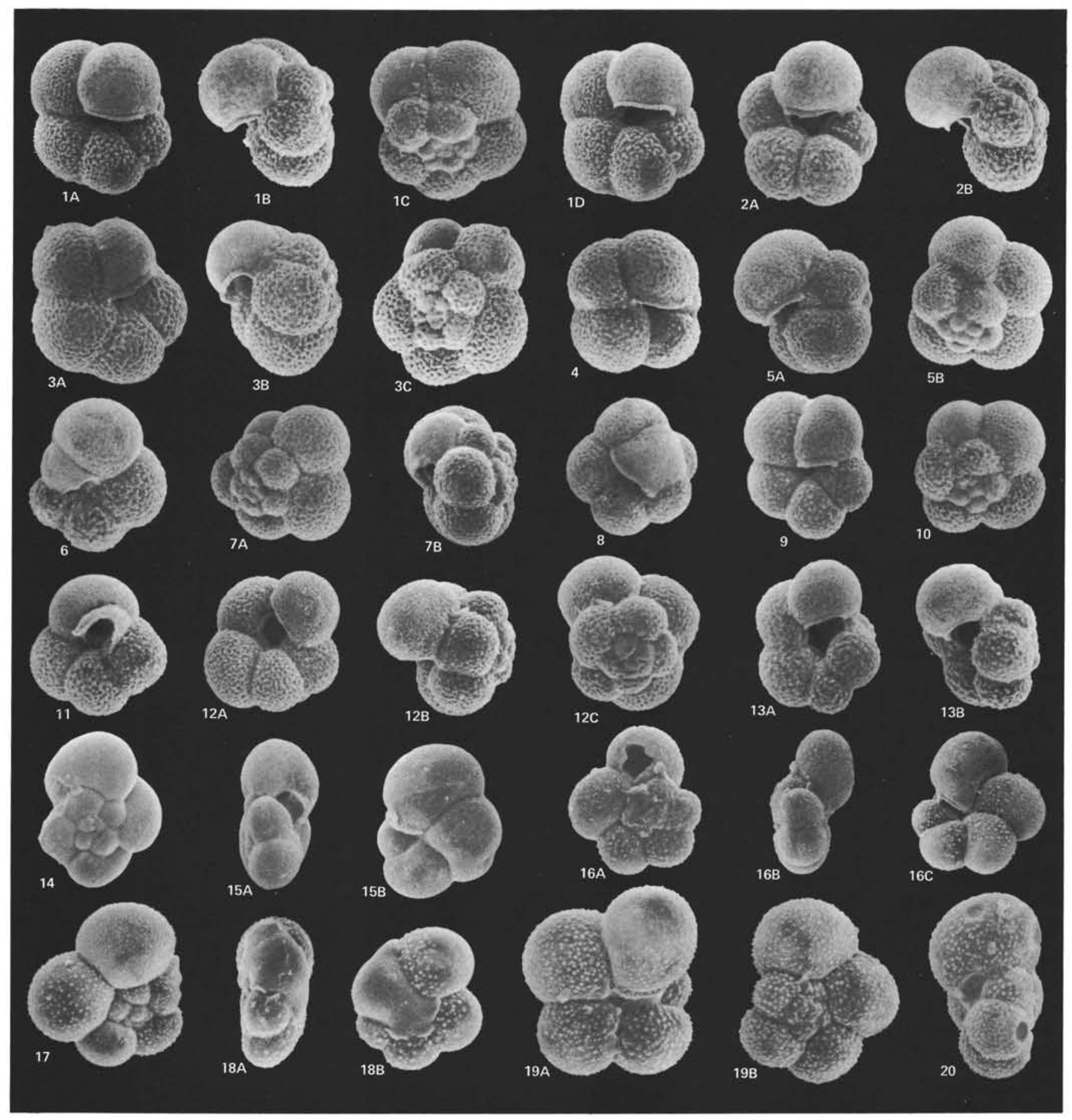

Plate 5. Late Pliocene to Holocene planktonic foraminifers. 1A-13B. Turborotalita guaymasensis Matoba and Oda $\mathrm{n}$. $\mathrm{sp} . \times 125 .(1) \mathrm{holotype} .(2-$

13) paratypes. (1A) umbilical view. (1B) side view. (1C) spiral view, slightly oblique. (1D) oblique umbilical view (IGPS Coll. Cat. 96730). (2A) oblique umbilical view. (2B) side view (IGPS Coll. Cat. 96731). (3A) umbilical view. (3B) side view. (3C) spiral view (IGPS Coll. Cat. 96732). (4) umbilical view (IGPS Coll. Cat. 96733). (5A) side view. (5B) oblique spiral view (IGPS Coll. Cat. 96734). (6) umbilical view (IGPS Coll. Cat. 96735). (7A) spiral view, slightly oblique. (7B) side view (IGPS Coll. Cat. 96736). (8, 9) umbilical views (IGPS Coll. Cat. 96737, 96738). (10) spiral view (IGPS Coll. Cat. 96739). (11) umbilical view (IGPS Coll. Cat. 96740). (12A) oblique umbilical view. (12B) side view. (12C) spiral view (IGPS Coll. Cat. 96741). (13A) umbilical view, slightly oblique. (13B) side view (IGPS Coll. Cat. 96742). (1-12) Sample 478-22-1, 28-31 cm. (13) Sample 479-7-4, 46-48 cm. 14-15B. Turborotalita anfracta (Parker). $\times 130$. (14) spiral view (AKMG 11040a). (15A) side view. (15B) umbilical view (AKMG 11040b). Section 481-3,CC. 16A-C. Turborotalita cf. T. parkerae Brönnimann and Resig. $\times 130$. (16A) spiral view. (16B) side view. (16C) umbilical view (AKMG 11041). Section 480-16,CC. 17-18B. Turborotalita iota $($ Parker). $\times 125$. (17) spiral view (AKMC 11042a). (18A) side view. (18B) umbilical view (AKMG 11042b). Section 481-3,CC. 19A-20. Turborotalita iota (Parker) vars. $\times 130$. (19A) umbilical view. (19B) spiral view (last chamber of Fig. 19A broken) (AKMG 11043a). (20) side view (AKMG 11043b). Sample 478-22-1, 28-31 cm. 